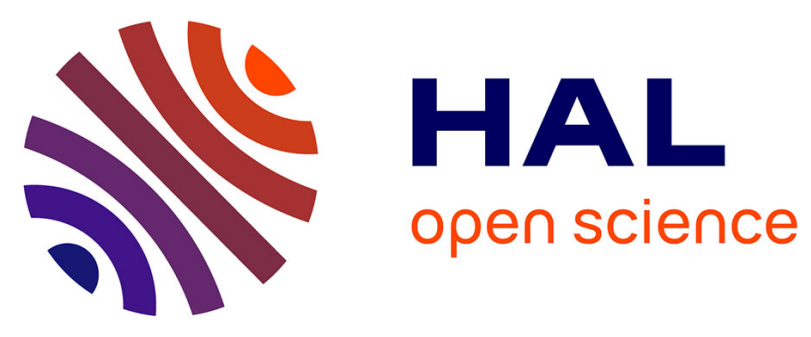

\title{
Triterpene saponins from Silene gallica collected in North-Eastern Algeria
}

Sara Bechkri, Abdulmagid Alabdul Magid, Charlotte Sayagh, Djemaa Berrehal, Dominique Harakat, Laurence Voutquenne-Nazabadioko, Zahia Kabouche, Ahmed Kabouche

\section{To cite this version:}

Sara Bechkri, Abdulmagid Alabdul Magid, Charlotte Sayagh, Djemaa Berrehal, Dominique Harakat, et al.. Triterpene saponins from Silene gallica collected in North-Eastern Algeria. Phytochemistry, 2020, 172, pp.112274. 10.1016/j.phytochem.2020.112274 . hal-02490507

\section{HAL Id: hal-02490507 https://hal.univ-reims.fr/hal-02490507}

Submitted on 9 Sep 2021

HAL is a multi-disciplinary open access archive for the deposit and dissemination of scientific research documents, whether they are published or not. The documents may come from teaching and research institutions in France or abroad, or from public or private research centers.
L'archive ouverte pluridisciplinaire HAL, est destinée au dépôt et à la diffusion de documents scientifiques de niveau recherche, publiés ou non, émanant des établissements d'enseignement et de recherche français ou étrangers, des laboratoires publics ou privés. 


\section{Triterpene saponins from Silene gallica collected in North-eastern Algeria}

Sara Bechkri ${ }^{\mathrm{a}, \mathrm{b}}$, Abdulmagid Alabdul Magid ${ }^{\mathrm{b}}$, Charlotte Sayagh ${ }^{\mathrm{b}}$, Djemaa Berrehal ${ }^{\mathrm{a}}$, Dominique Harakat $^{\mathrm{b}}$, Laurence Voutquenne-Nazabadioko ${ }^{\mathrm{b}}$, Zahia Kabouche, Ahmed Kabouche ${ }^{\mathrm{a}, *}$

${ }^{a}$ Université des frères Mentouri-Constantine 1, Département de chimie, Laboratoire d'Obtention des Substances Thérapeutiques (LOST), Campus Chaabet-Ersas, 25000 Constantine, Algeria ${ }^{\mathrm{b}}$ Université de Reims Champagne Ardenne, CNRS, ICMR UMR 7312, 51097 Reims, France

\section{* Corresponding author.}

E-mail address: ahmedkabouche6@gmail.com (A. Kabouche) 


\begin{abstract}
Eleven previously undescribed triterpene saponins, named silenegallisaponin A-K (1-11), were isolated from the aerial parts of Silene gallica $\mathrm{L}$. Their structures were elucidated by analysis of 1Dand 2D-NMR spectroscopic data and mass spectrometry (HR-ESI-MS). The saponins comprised caulophyllogenin, echinocystic acid, or quillaic acid substituted at C-3 by a $\beta$-D-glucuronic acid or $\beta$-D-galactopyranosyl-( $1 \rightarrow 3)-\beta$-D-glucuronopyranoside and at $\mathrm{C}$-28 by a $\beta$-D-fucopyranose substituted at C-2 by $\beta$-D-glucose and at C-3 by a $\beta$-D-glucose or a $\beta$-D-quinovose.
\end{abstract}

Keywords: Silene gallica, Caryophyllaceae, triterpene saponins. 


\section{Introduction}

The genus Silene, belonging to the family Caryophyllaceae, contains more than 700 species mainly distributed in temperate regions of the Northern Hemisphere of Eurasia and America, but also in Africa (Mamadalieva et al., 2014). The genus consists mainly of herbaceous plants and, more rarely, small shrubs or subshrubs (Mamadalieva et al., 2014). Phytochemical investigations of the genus Silene have led to the isolation of several phytoecdysteroids (Mamadalieva et al., 2014), triterpene saponins (Gaidi et al., 2002), benzenoids, flavonoids (Darmograi et al., 1977), anthocyanins, N-containing compounds (Dötterl et al., 2005), sterols, and vitamins (Arnetoli et al., 2008; Eshmirzaeva et al., 2005). The abundance and widespread occurrence of triterpene saponins are typical features of the family Caryophyllaceae. Previous investigations of Silene plants led to isolation of approximately 52 triterpenoid saponins (Böttger and Melzig 2011; Mamadalieva et al., 2014). Silene gallica L., native to central Europe, is an annual species growing to $0.4 \mathrm{~m}$ in height (Asai and Fujimoto, 2010). To our knowledge, saponins have not been isolated from S. gallica however, ten cyclic fatty acyl glycosides were previously reported from the glandular trichome exudate (Asai and Fujimoto, 2010). Here, we report the isolation and structure elucidation of eleven undescribed triterpene saponins from the aerial parts of $S$. gallica L. Their structures were elucidated by spectroscopic methods including $1 \mathrm{D}$ - and $2 \mathrm{D}-\mathrm{NMR}$ experiments $\left({ }^{1} \mathrm{H},{ }^{13} \mathrm{C}\right.$, HSQC, HMBC, COSY, ROESY), in combination with HR-ESI-MS.

\section{Results and discussion}

A ethanol/water $(80 / 20 \mathrm{v} / \mathrm{v})$ extract of the aerial part of $S$. gallica was suspended in $\mathrm{H}_{2} \mathrm{O}$ and partitioned successively with petroleum ether, $\mathrm{CHCl}_{3}$, EtOAc and $n$ - $\mathrm{BuOH}$. The $n$ - $\mathrm{BuOH}$-soluble fraction was purified by repeated chromatography on normal and reversed phase RP-18 silica gel yielding eleven triterpenoid saponins (1-11). 
Compound 1 exhibited, in the HR-ESI-MS (positive ion mode), a quasimolecular ion peak at $\mathrm{m} / \mathrm{z}$ 1157.5367 $[\mathrm{M}+\mathrm{Na}]^{+}$, consistent with the molecular formula $\mathrm{C}_{54} \mathrm{H}_{86} \mathrm{O}_{25}$. The presence of six tertiary methyl groups $\left(\delta_{\mathrm{H}} 0.72,0.79,0.91,0.97,1.02\right.$, and 1.37$)$ and one tri-substituted olefinic proton $\left(\delta_{\mathrm{H}}\right.$ 5.32, $\mathrm{t}, J=3.7 \mathrm{~Hz}, \mathrm{H}-12$ ) in the ${ }^{1} \mathrm{H}-\mathrm{NMR}$ spectrum (Table 1) and six $\mathrm{sp}^{3}$ carbons eombined with data from ${ }^{13} \mathrm{CNMR}$ spectrum (six sp ${ }^{3}$ at $\delta_{\mathrm{C}} 12.0,15.2,16.5,23.7,26.0$, and 32.131 .9 with and two $\mathrm{sp}^{2}$ olefinic carbons $\left(\delta_{\mathrm{C}} 121.9\right.$ and 143.5$)$ in the ${ }^{13} \mathrm{C}-\mathrm{NMR}$ indicated that compound $\mathbf{1}$ possesses an olean-12-ene skeleton (Lehbili et al., 2018 Boutaghane et al., 2013). Furthermore, signals for one oxygenated methylene $\left(\delta_{\mathrm{C}} 63.3 / \delta_{\mathrm{H}} 3.29\right.$ and 3.63$)$, two oxygenated methines $\left(\delta_{\mathrm{C}} 82.0 / \delta_{\mathrm{H}} 3.66\right.$, and $\left.\delta_{\mathrm{C}} 72.7 / \delta_{\mathrm{H}} 4.78\right)$ and one carboxyl group $\left(\delta_{\mathrm{C}} 175.7\right)$ were observed in ${ }^{13} \mathrm{C}-\mathrm{NMR}$ and ${ }^{1} \mathrm{H}-\mathrm{NMR}$ spectra. Through an extensive 2D-NMR study, the aglycone was identified as $3 \beta, 16 \alpha, 23$ trihydroxyolean-12-en-28-oic acid, commonly named caulophyllogenin, which is in good agreement with literature data (Table 1) (Matsuo et al., 2009). The chemical shift values of C-3 $\left(\delta_{\mathrm{C}}\right.$ 82.0) and C-28 $\left(\delta_{\mathrm{C}} 175.7\right)$ suggested that the saponin was a bisdesmosidic glycoside with saccharide units attached to these positions (Lehbili et al., 2017 and 2018). The HMBC spectrum showed cross-peaks between $\mathrm{H}-16$ signal with $\mathrm{C}-14, \mathrm{C}-15, \mathrm{C}-17, \mathrm{C}-18$ and C-22, thus unambiguously locating the hydroxyl group at C-16 $\left(\delta_{\mathrm{C}} 72.7\right)$. The $16 \alpha$-configuration of hydroxyl group was evident from the small $J$ values of $\mathrm{H}-16$ and $\mathrm{H}-15(J=3.5 \mathrm{~Hz})$, characteristic of an equatorial proton (Lehbili et al., 2017). Moreover, ROESY correlation was observed between Me-26 $\left(\delta_{\mathrm{H}} 0.79\right)$ and H$16 \beta$-oriented-while no one was observed between Me-27 $\left(\delta_{\mathrm{H}} 1.37\right)$ an $\mathrm{H}-16$ confirming that $\mathrm{H}-16$ had $\beta$-configuration. The $\alpha$-configuration of $\mathrm{H}-3\left(\delta_{\mathrm{H}} 3.66\right)$ was indicated by the coupling constants of proton $\mathrm{H}-3$ with the protons $\mathrm{H}-2(\mathrm{~J}=12.5$ and $5.0 \mathrm{~Hz})$, characteristic of an axial proton. This assumption was confirmed by the ROESY correlation between $\mathrm{H}-3\left(\delta_{\mathrm{H}} 3.66\right) / \mathrm{H}-5\left(\delta_{\mathrm{H}} 1.26\right)$ and $\mathrm{H}-$ 5/H-9 $\left(\delta_{\mathrm{H}} 1.70\right) \alpha$-oriented. Furthermore, an HMBC cross-peak of $\delta_{\mathrm{H}-24} 0.72$ with $\delta_{\mathrm{C}-23} 63.3$ and a ROESY cross-peak between $\mathrm{H}-3$ and $\mathrm{H}_{2}-23\left(\delta_{\mathrm{H}} 3.29,3.63\right)$ suggested the location of the primary alcoholic function at C-23. 
The presence of four sugar moieties in $\mathbf{1}$ was evidenced by the ${ }^{1} \mathrm{H}$ NMR spectrum which displayed four their anomeric protons at $\delta_{\mathrm{H}} 4.48,4.63,4.88$, and 5.38, giving correlations with four the corresponding anomeric carbons at $\delta_{\mathrm{C}} 104.5,103.9,102.3$, and 92.6, respectively in the HSQC spectrum. A $\beta$-D-glucuronopyranose unit (glcA) was identified starting from the anomeric proton at $\delta_{\mathrm{H}} 4.48(\mathrm{~d}, J=7.8 \mathrm{~Hz})$, and characterized by a five spin system possessing large coupling constants $(J \geq 7.8 \mathrm{~Hz})$ in the COSY spectrum and by a carbonyl (C-6) resonating at $\delta_{\mathrm{C}} 171.3$ coupled with $\mathrm{H}-$ $5\left(\delta_{\mathrm{H}} 3.81, \mathrm{~d}, J=9.1 \mathrm{~Hz}\right)$ and $\mathrm{H}-4\left(\delta_{\mathrm{H}} 3.52, \mathrm{t}, J=9.3 \mathrm{~Hz}\right)$ of the same sugar in the HMBC. The ${ }^{13} \mathrm{C}-$ NMR signals of the glucuronic acid of $\mathbf{1}$ were fully determined in the HSQC experiments and revealed it to be in terminal position as summarized in Table 2 (Alabdul Magid et al., 2006). In the same manner, two $\beta$-D-glucopyranose units in terminal positions were identified starting from their anomeric protons $\left(\mathrm{glc} 1, \delta_{\mathrm{H}-1} 4.88, \mathrm{~d}, J=8.0 \mathrm{~Hz}\right.$; glc2, $\left.\delta_{\mathrm{H}-1} 4.63, \mathrm{~d}, J=7.5 \mathrm{~Hz}\right)$ and according to the large coupling constants $\left(J_{\mathrm{H}-1, \mathrm{H}-2}, J_{\mathrm{H}-2, \mathrm{H}-3}, J_{\mathrm{H}-3, \mathrm{H}-4}, J_{\mathrm{H}-4, \mathrm{H}-5} \geq 7.5 \mathrm{~Hz}\right)$ and their carbon chemical shift values (Table 2) (Boutaghane et al., 2018). The last sugar unit was identified as $\beta$-D-fucopyranose (fuc) $\left(\delta_{\mathrm{H}-1} 5.38, \mathrm{~d}, J=8.2 \mathrm{~Hz}\right)$ based on the large coupling constants $J_{\mathrm{H}-1, \mathrm{H}-2}$ and $J_{\mathrm{H}-2, \mathrm{H}-3}(\geq 8.2 \mathrm{~Hz})$ and the small coupling constant between $\mathrm{H}-3$ and $\mathrm{H}-4(\mathrm{~J}=3.0 \mathrm{~Hz})$ and the doublet methyl proton signal at $\delta_{\mathrm{H}} 1.27(\mathrm{~d}, J=6.4 \mathrm{~Hz}, \mathrm{H}-6)$, as summarized in Table 2 (Voutquenne-Nazabadioko et al., 2013). The $\beta$-D-fucopyranose unit was found to be substituted in-at the C-2 $\left(\delta_{\mathrm{C}} 73.3\right)$ and $\mathrm{C}-3\left(\delta_{\mathrm{C}}\right.$ 84.0) positions (Table 2). The anomeric configurations $(\beta)$ were determined by the $J_{\mathrm{H}-1-\mathrm{H}-2}$ coupling constants and the comparison of ${ }^{13} \mathrm{C}-\mathrm{NMR}$ data with those in the literature (Table 2) (Agrawal, 1992). The steric series (D) were determined after acid hydrolysis of the saponin mixture (see experimental). The rOe interactions observed in the ROESY spectrum between $\mathrm{H}-1, \mathrm{H}-3$ and $\mathrm{H}-5$ of each sugar unit confirmed the $\alpha$-axial orientation of these protons and the $\beta$-anomeric configuration. Complete assignments of the proton and carbon resonances of all the sugars were achieved by extensive 1D and 2D NMR analyses (Table 2). The sequence and the attachment of each saccharide were determined by analysis of HMBC and ROESY spectra. The cross-peaks observed in the HMBC spectrum between H-1-glc1/C-2-fuc, H-1-glc2/fuc-C-3, and H-1-fuc/aglycone-C-28 
indicated that a $\beta$-D-fucopyranose disubstituted at C-2 and C-3 positions by two $\beta$-D-glucopyranose units was linked to C-28 of caulophyllogenin. The glycosylation at C-3 of the aglycone was confirmed as a $\beta$-D-glucuronopyranose moiety, through HMBC correlation of H-1-glcA to C-3caulophyllogenin. In addition, ROESY correlations, confirming the interglycosidic linkage of the trisaccharide and the point of attachment of glcA at the C-3 of the aglycone, were observed between H-1-glcA-/H-3-aglycone, H-1-glc1/H-2-fuc, and H-1-glc2 /H-3-fuc. Based on the above spectral data, the structure of $\mathbf{1}$ was identified as 3-O- $\beta$-D-glucuronopyranosyl caulophyllogenin $28-O-\beta$-Dglucopyranosyl-(1 $\rightarrow 3)$-[ $\beta$-D-glucopyranosyl-( $1 \rightarrow 2)]$ - $\beta$-D-fucopyranoside, named silenegallisaponin A (Fig. 1).

Compound 2 gave, in the positive HR-ESI-MS, a quasimolecular ion peak at $\mathrm{m} / z 1199.5454$ $[\mathrm{M}+\mathrm{Na}]^{+}\left(\right.$calcd for $\left.\mathrm{C}_{56} \mathrm{H}_{88} \mathrm{O}_{26} \mathrm{Na}, 1199.5462\right)$, suggesting the presence of a supplementary acetyl group (42 amu) compared to compound 1. The structural analysis revealed that the NMR signals of the aglycone part of $\mathbf{2}$ were superimposable to those of $\mathbf{1}$ (Table 1). The ${ }^{1} \mathrm{H}$ - and ${ }^{13} \mathrm{C}-\mathrm{NMR}$ data of the sugar portion of $\mathbf{2}$ were closely comparable to those of $\mathbf{1}$, except for the signals of the glucose moiety (glc1) and the presence of an additional signals for of an acetyl group $\left(\delta_{\mathrm{H}} 2.14\right.$ and $\delta_{\mathrm{C}} 19.8$, $\mathrm{CH}_{3}$ ) and $171.4(\mathrm{CO})$ (Table 2). The $\beta$-D-glucopyranose (glc1) possessed a deshielded proton $\mathrm{H}-3$ at $\delta_{\mathrm{H}} 4.92$, indicating the linkage of the acetyl group. This was readily confirmed by the HMBC correlation between $\mathrm{H}-3$-glc1 and the carbonyl signal $\left(\delta_{\mathrm{C}} 171.4\right)$ of the acetyl group. Full assignments of the proton and carbon resonances of the aglycone and the sugar parts were achieved by analysis of the COSY, HSQC, HMBC, and ROESY spectra (Tables 1 and 2). The sequence and the attachment of the saccharide units in $\mathbf{2}$ were confirmed as in $\mathbf{1}$ by HMBC and ROESY experiments. On the basis of the above analysis, the structure of 2 was established as 3-O- $\beta$-Dglucuronopyranosyl caulophyllogenin $\quad 28-O-\beta$-D-glucopyranosyl-( $1 \rightarrow 3)$-[3- $O$-acetyl- $\beta$-Dglucopyranosyl-(1 $\rightarrow 2)$ ]- $\beta$-D-fucopyranoside, named silenegallisaponin B (Fig. 1).

Compound 3 displayed in the positive HR-ESI-MS a quasimolecular ion peak $[\mathrm{M}+\mathrm{Na}]^{+}$at $\mathrm{m} / \mathrm{z}$ 1137.4926 (calcd for $\mathrm{C}_{50} \mathrm{H}_{78} \mathrm{O}_{21} \mathrm{Na}, 1037.4933$ ), suggesting the lack of one hexose unit compared to 
2. Furthermore, the appearance of three pair of anomeric proton and carbon signals in the ${ }^{1} \mathrm{H}-$ and ${ }^{13} \mathrm{C}$-NMR spectra (Table 2) confirmed the presence of three sugar units. Comparison of the ${ }^{1} \mathrm{H}$ - and ${ }^{13} \mathrm{C}-\mathrm{NMR}$ values and the analysis of the HMBC and ROESY correlations showed that 2 and $\mathbf{3}$ contained the same aglycone (Table 1). The detailed analysis of the 2D-NMR spectra led to the identification of caulophyllogenin as aglycone, an acetyl group (ac), and three sugar units: a terminal $\beta$-D-glucuronopyranose (glcA), a $\beta$-D-glucopyranose (glc), and a $\beta$-D-fucopyranose (fuc). The HMBC spectrum of 3 showed long-range correlations between H-3-glc/C-1-ac, H-1-glc/C-2fuc, H-1-fuc/C-28-aglycone, H-1-glcA/C-3-aglycone. These findings led to the assignment of compound $\mathbf{3}$ as 3-O- $\beta$-D-glucuronopyranosyl caulophyllogenin $\quad 28-O$-[3- $O$-acetyl- $\beta$-Dglucopyranosyl-(1 $\rightarrow 2)]-\beta$-D-fucopyranoside, named silenegallisaponin C (Fig. 1).

Compound 4 gave in the positive HR-ESI-MS a quasimolecular ion peak at $\mathrm{m} / \mathrm{z} 1199.5455$ $[\mathrm{M}+\mathrm{Na}]^{+}$(calcd for $\left.\mathrm{C}_{56} \mathrm{H}_{88} \mathrm{O}_{26} \mathrm{Na}, 1199.5462\right)$ in agreement with a molecular formula of $\mathrm{C}_{56} \mathrm{H}_{88} \mathrm{O}_{26}$ which was an isomeric with compound 2. Inspection of the spectroscopic data indicated that saponin 4 had the same aglycone (caulophyllogenin) and glycoside parts as saponin 2 (fuc: $\delta_{\mathrm{H}-1}$ 5.40, glcA: $\delta_{\mathrm{H}-1} 4.48$, glc1: $\delta_{\mathrm{H}-1} 4.93$, glc2: $\delta_{\mathrm{H}-1} 4.61$ ) and an acetyl group (Table 2). The ${ }^{1} \mathrm{H}-$ and ${ }^{13} \mathrm{C}-\mathrm{NMR}$ data of the sugar portion of $\mathbf{4}$ were closely comparable to those of $\mathbf{2}$, except for the signals of the glucose moiety (glc1). Glc1 possessed-a deshielded protons $\mathrm{H}_{2}-6\left(\delta_{\mathrm{H}} 4.35\right.$ and 4.389$)$ indicating the position of the acetyl group. These results suggested that compound $\mathbf{4}$ is a regioisomer of 2 with the acetate attached to C-6-glc1 rather than to C-3-glc1 (Table 2). This was confirmed by the HMBC correlation between $\mathrm{H}_{2}-6$-glc1 and the carbonyl signal $\left(\delta_{\mathrm{C}} 172.3\right)$ of the acetyl group. The sequence and the attachment of the saccharide chains in $\mathbf{4}$ were confirmed as in $\mathbf{2}$ by HMBC and ROESY experiments. Thus, the structure of compound 4 was established as 3-O- $\beta$ D-glucuronopyranosyl caulophyllogenin $\quad 28-O-\beta$-D-glucopyranosyl-( $1 \rightarrow 3)$-[6- $O$-acetyl- $\beta$-Dglucopyranosyl-(1 $\rightarrow 2)]$ - $\beta$-D-fucopyranoside, named silenegallisaponin D (Fig. 1).

Compound 5 exhibited in the positive HR-ESI-MS a quasimolecular ion peak at $\mathrm{m} / \mathrm{z} 1183.5502$ $[\mathrm{M}+\mathrm{Na}]^{+}\left(\right.$calcd $\left.\mathrm{C}_{56} \mathrm{H}_{88} \mathrm{O}_{25} \mathrm{Na}, 1183.5512\right)$, suggesting one oxygen less than that of 2. Comparison 
of the ${ }^{13} \mathrm{C}-\mathrm{NMR}$ data of $\mathbf{5}$ to those of $\mathbf{2}$ and analysis of the 2D-NMR spectra of $\mathbf{5}$ showed that both possessed a glcA at $\mathrm{C}-3$ and the trisaccharide chain glc $(1 \rightarrow 3)$-[3- $O$-acetyl-glc $(1 \rightarrow 2)]-$ fuc- at C-28 of the aglycone (Table 2). The difference was the absence of the hydroxymethylene group ($\left.\mathrm{CH}_{2} \mathrm{OH}-23\right)$ of the aglycone. An extra methyl moiety was detected in $5\left(\delta_{\mathrm{H}} 1.08\right)$. The HMBC spectrum revealed proper correlations for this methyl group with $\mathrm{C}-4\left(\delta_{\mathrm{C}} 38.8\right), \mathrm{C}-5\left(\delta_{\mathrm{C}} 55.7\right), \mathrm{C}-3$ $\left(\delta_{\mathrm{C}} 89.6\right)$, as well as $\mathrm{C}-24\left(\delta_{\mathrm{C}} 15.6\right)$. The chemical shifts values for all protons and carbons of the aglycone moiety (Table 1) were in accordance with the literature data of echinocystic acid $(3 \beta, 16 \alpha-$ dihydroxyolean-12-en-28-oic acid) (Lehbili et al., 2017), which was further confirmed by COSY, HSQC, HMBC and ROESY experiments on 5. Consequently, the structure of 5 was concluded to be 3-O- $\beta$-D-glucuronopyranosyl echinocystic acid $28-O-\beta$-D-glucopyranosyl-( $1 \rightarrow 3)$-[3- $O$-acetyl- $\beta$ D-glucopyranosyl(1 $\rightarrow 2)]-\beta$-D-fucopyranoside, named silenegallisaponin E (Fig. 1).

Compound 6 had a molecular formula of $\mathrm{C}_{56} \mathrm{H}_{86} \mathrm{O}_{26}$ according to the HR-ESI-MS quasi molecular ion peak at $\mathrm{m} / z 1197.5298[\mathrm{M}+\mathrm{Na}]^{+}$(calcd for $\left.\mathrm{C}_{56} \mathrm{H}_{86} \mathrm{O}_{26} \mathrm{Na}, 1197.5305\right)$. The 2D-NMR analysis showed that compounds $\mathbf{5}$ and $\mathbf{6}$ differed only in the aglycone part at C-23 position (Tables 1 and 2). The methyl group $\mathrm{CH}_{3}-23$ signals $\left(\delta_{\mathrm{H}} 1.08, \delta_{\mathrm{C}} 27.1\right)$ in 5 was replaced by an aldehyde function $\left(\delta_{\mathrm{H}} 9.44, \delta_{\mathrm{C}} 207.5\right)$ in 6 . Full assignments of the proton and carbon resonances of the aglycone and the sugar parts were achieved by analysis of the COSY, HSQC and HMBC spectra (Tables 1 and 2). The triterpene skeleton of $\mathbf{6}$ was thus determined as the known quillaic acid ( $3 \beta, 16 \alpha$-dihydroxy23-oxoolean-12-en-28-oic acid) (Takahashi et al., 2016). The sequence and the attachment of the saccharide units in $\mathbf{6}$ were confirmed as in $\mathbf{5}$ by an HMBC and ROESY experiments. Thus, the structure of $\mathbf{6}$ was elucidated as 3-O- $\beta$-D-glucuronopyranosyl quillaic acid $28-O-\beta$-Dglucopyranosyl-(1 $\rightarrow 3)$-[3- $O$-acetyl- $\beta$-D-glucopyranosyl-( $1 \rightarrow 2)]-\beta$-D-fucopyranoside, $\quad$ named silenegallisaponin F (Fig. 1).

Compound 7 showed, in the positive HR-ESI-MS, a quasimolecular ion peak at $m / z 1319.5870$ [M $+\mathrm{Na}]^{+}\left(\right.$calcd $\left.\mathrm{C}_{60} \mathrm{H}_{96} \mathrm{O}_{30} \mathrm{Na}, 1319.5884\right)$. Comparison of the NMR data of $\mathbf{7}$ with $\mathbf{1}$ and detailed analysis of the 2D-NMR spectra showed that they possessed the same saccharide and aglycone 
(caulophyllogenin) pattern but with the presence of one supplementary sugar moiety in $\mathbf{7}$ (Tables 3 and 4). Analysis of COSY and HSQC spectra, allowed assignment of this additional monosaccharide as a terminal $\beta$-D-galactopyranose unit (gal) $\left(\delta_{\mathrm{H}-1} 4.57, \mathrm{~d}, J=7.8 \mathrm{~Hz} ; \delta_{\mathrm{C}-1} 104.0\right)$, characterized by the large coupling constants $J_{\mathrm{H}-1, \mathrm{H}-2}$ and $J_{\mathrm{H}-2, \mathrm{H}-3}(>7.8 \mathrm{~Hz})$ and the small coupling constant between $\mathrm{H}-3$ and $\mathrm{H}-4\left(J_{\mathrm{H}-3, \mathrm{H}-4}=3.4 \mathrm{~Hz}\right)$ as summarized in Table 4 (Lehbili et al., 2018). The deshielded signals of C-3-glcA $\left(\delta_{\mathrm{C}} 84.9\right)$ indicated that galactopyranose moiety was attached to C-3 of the glucuronopyranose unit. This was confirmed by the HMBC correlation between H-1-gal and C-3-glcA. Thus, the structure of 7 was established as $3-O-\beta$-D-galactopyranosyl-( $1 \rightarrow 3)-\beta$-Dglucuronopyranosyl caulophyllogenin $\quad 28-O-\beta$-D-glucopyranosyl-( $1 \rightarrow 3)$-[ $\beta$-D-glucopyranosyl$(1 \rightarrow 2)]$ - $\beta$-D-fucopyranoside, named silenegallisaponin G (Fig. 1).

Compound 8 exhibited, in the positive HR-ESI-MS, a molecular ion at $\mathrm{m} / z 1361.5981[\mathrm{M}+\mathrm{Na}]^{+}$ (calcd for $\mathrm{C}_{62} \mathrm{H}_{98} \mathrm{O}_{31} \mathrm{Na}$, 1361.5990), suggesting a supplementary acetyl unit compared to compound 7. The ${ }^{1} \mathrm{H}$ - and ${ }^{13} \mathrm{C}-\mathrm{NMR}$ data of compound 8 were closely comparable to those of $\mathbf{7}$ except for the signals of $\beta$-D-glucopyranose unit (glc1) and the presence of one acetyl group $\left(\delta_{\mathrm{H}}\right.$ 2.18; $\left.\delta_{\mathrm{C}} 19.8,172.3\right)$ (Tables 3 and 4$)$. The glc1 possessed two deshielded protons $\mathrm{H}_{2}-6\left(\delta_{\mathrm{H}} 4.35\right.$, 4.39), indicating the position of the acetyl group. This was confirmed by the HMBC correlation between H-6-glc1 and the carbonyl signal of the acetyl group. Assignments of all proton and carbon resonances of $\mathbf{8}$ were completed by extensive analysis of the 2D-NMR spectra (Tables 3 and 4). The HMBC correlations showed that the sugars were attached in the same way in both saponins $\mathbf{7}$ and $\mathbf{8}$. Consequently, the structure of $\mathbf{8}$ was concluded to be $3-O-\beta$-D-galactopyranosyl( $1 \rightarrow 3)-\beta$-Dglucuronopyranosyl caulophyllogenin $\quad 28-O$ - $\beta$-D-glucopyranosyl-( $1 \rightarrow 3)$-[6- $O$-acetyl- $\beta$-Dglucopyranosyl-(1 $\rightarrow 2)]$ - $\beta$-D-fucopyranoside, named silenegallisaponin H (Fig. 1).

Compound 9 exhibited, in the positive HR-ESI-MS, a molecular ion peak at $\mathrm{m} / \mathrm{z} 1183.5503$ $[\mathrm{M}+\mathrm{Na}]^{+}$(calcd for $\mathrm{C}_{56} \mathrm{H}_{88} \mathrm{O}_{25} \mathrm{Na}, 1183.5512$ ), suggesting a supplementary deoxyhexose unit compared to saponin 3. The ${ }^{1} \mathrm{H}$ - and ${ }^{13} \mathrm{C}$-NMR resonances of the aglycone of 9 matched well with the signals of $\mathbf{3}$ indicating the same aglycone and one acetyl group for both compounds. The ${ }^{1} \mathrm{H}-$ 
NMR spectrum of 9 showed indeed the occurrence of four anomeric signals at $\delta_{\mathrm{H}} 4.59,5.04$, and 5.40. Complete assignments of each sugar were achieved by extensive 1D- and 2D-NMR analyses, allowing the identification of one $\beta$-glucuronopyranose, one $\beta$-fucopyranose, and one $\beta$ glucopyranose units, as in 3. Th e fourth sugar unit $\left(\delta_{\mathrm{H}-1} 4.59 \mathrm{~d}, J=7.6 \mathrm{~Hz}\right)$ was identified as terminal $\beta$-quinovopyranose unit (qui) as ascertained from the analysis of $2 \mathrm{D}$-NMR spectra, based on the large coupling constants between $J_{\mathrm{H}-1, \mathrm{H}-2}, J_{\mathrm{H}-2, \mathrm{H}-3}, J_{\mathrm{H} 3-, \mathrm{H}-4}, J_{\mathrm{H}-4, \mathrm{H}-5}(J \geq 7.6 \mathrm{~Hz})$ and the doublet methyl proton signal at $\delta_{\mathrm{H}} 1.28(\mathrm{~d}, J=6.4 \mathrm{~Hz}, \mathrm{H}-6)$, as summarized in Table 4 (Pertuit et al. 2014). The deshielded signals of C-3-fuc $\left(\delta_{\mathrm{C}} 83.9\right)$ indicated that the additional quinovopyranose moiety was attached to C-3 of the fucopyranose unit. A HMBC cross-peak between the signals of H-1-glcA $\left(\delta_{\mathrm{H}} 4.48\right)$ and $\mathrm{C}$-3-aglycone $\left(\delta_{\mathrm{C}} 82.0\right)$ confirmed the presence of a $\beta$-D-glucuronopyranosyl unit linked at C-3 of the aglycone. The sequence of the trisaccharide chain at C-28 was established by the HMBC cross-peaks between H-1-fuc $\left(\delta_{\mathrm{H}} 5.40\right) / \mathrm{C}-28\left(\delta_{\mathrm{C}} 175.6\right), \mathrm{H}-1$-glc $\left(\delta_{\mathrm{H}} 5.04\right) / \mathrm{C}-2-\mathrm{fuc}\left(\delta_{\mathrm{C}}\right.$ 73.1), H-1-qui/C-3-fuc, and H-3-glc $\left(\delta_{\mathrm{H}} 4.91\right) / \mathrm{C}-1-$ Acetyl $\left(\delta_{\mathrm{C}} 171.4\right)$. Therefore, compound 9 was identified as 3-O- $\beta$-D-glucuronopyranosyl caulophyllogenin $28-O-\beta$-D-quinovopyranosyl-(1 $\rightarrow 3)$-[3$O$-acetyl- $\beta$-D-glucopyranosyl-(1 $\rightarrow 2)]-\beta$-D-fucopyranoside, named silenegallisaponin I (Fig. 1).

Compound 10 showed, in the positive HR-ESI-MS, a molecular ion peak at $\mathrm{m} / z 1141.5413$ $[\mathrm{M}+\mathrm{Na}]^{+}$(calcd for $\left.\mathrm{C}_{54} \mathrm{H}_{86} \mathrm{O}_{24} \mathrm{Na}, 1141.5407\right)$. The ${ }^{1} \mathrm{H}-$ and ${ }^{13} \mathrm{C}-\mathrm{NMR}$ spectra of $\mathbf{1 0}$ displayed many similarities with those of $\mathbf{9}$, especially for the resonances assigned to caulophyllogenin and $\beta$ glucuronopyranosyl, $\beta$-fucopyranosyl, $\beta$-glucopyranosyl and $\beta$-quinovopyranosyl units. However, those attributed to the acetyl group were absent (Tables 3 and 4). The identities of the monosaccharides were determined by detailed analysis of the 2D-NMR spectra. An HMBC experiment made clear all interglycosidic connectivities showing correlations between $\mathrm{H}-1$-glcA $\left(\delta_{\mathrm{H}}\right.$ 4.48)/C-3-aglycone $\left(\delta_{\mathrm{C}} 81.9\right), \mathrm{H}-1$-fuc $\left(\delta_{\mathrm{H}} 5.38\right) / \mathrm{C}-28$-aglycone $\left(\delta_{\mathrm{C}} 175.7\right), \mathrm{H}-1$-glc $\left(\delta_{\mathrm{H}} 4.63\right) / \mathrm{C}-32-$ fuc $\left(\delta_{\mathrm{C}} 83.7\right)$, and H-1-qui $\left(\delta_{\mathrm{H}} 4.89\right) / \mathrm{C}-23-$ fuc $\left(\delta_{\mathrm{C}} 73.4\right)$. Consequently, the structure of compound 10 was concluded to be 3-O- $\beta$-D-glucuronopyranosyl caulophyllogenin 28-O- $\beta$-D- 
quinovopyranosyl-(1 $\rightarrow 3)$-[ $\beta$-D-glucopyranosyl-( $1 \rightarrow 2)]-\beta$-D-fucopyranoside, silenegallisaponin $\mathbf{J}$ (Fig. 1).

Compound 11 had the molecular formula $\mathrm{C}_{60} \mathrm{H}_{96} \mathrm{O}_{29}$, deduced from the molecular ion peak, observed in its HR-ESI-MS at $m / z$ 1303.5925 [M+Na] ${ }^{+}$(calcd for $\mathrm{C}_{60} \mathrm{H}_{96} \mathrm{O}_{29} \mathrm{Na}, 1303.5935$ ), suggesting a supplementary hexose unit compared to saponin 10. The 1D-NMR, COSY, TOCSY, HSQC, HMBC and ROESY spectra of $\mathbf{1 1}$ compared with those of $\mathbf{1 0}$ revealed that they share the same trisaccharide sequence at C-28 of the caulophyllogenin $[\beta$-D-glequi- $(1 \rightarrow 3)-[\beta$-D-quiglc$(1 \rightarrow 2)]-\beta$-D-fuc-], and differed only by the saccharide chain at C-3, which was identified by comparison of NMR spectra of $\mathbf{1 1}$ and $\mathbf{7}$ as the disaccharide $\beta$-D-gal-( $1 \rightarrow 3)-\beta$-D-glcA- (Tables 3 and 4). Assignments of all proton and carbon resonances of $\mathbf{1 1}$ were achieved by analysis of the 2D NMR spectra (Tables 3 and 4). Thus, the structure of 11 was established as 3-O- $\beta$-Dgalactopyranosyl-(1 $\rightarrow 3)-\beta$-D-glucuronopyranosyl caulophyllogenin $28-O-\beta-\mathrm{D}-$ glueøquinovopyranosyl-( $1 \rightarrow 3)$-[ $\beta$-D-quinøvoglucopyranosyl-( $1 \rightarrow 2)]-\beta$-D-fucopyranoside, $\quad$ named silenegallisaponin K (Fig. 1).

\section{Conclusions}

Plants of the genus Silene have proved to be a rich source of triterpenoid saponins with oleanane type skeleton. Approximately 52 triterpenoid saponins were isolated from 9 Silene species till date: S. jenisseensis (Lacaille-Dubois et al., 1997), S. vulgaris (Bouguet-Bonnet et al., 2002; Glensk et al., 1999; Larhsini et al., 2003), S. fortunei (Gaidi et al., 2002; Lacaille-Dubois et al. 1999), S. rubicunda (Fu et al., 2005; Wu et al., 2014 and 2015), S. brahuica (Sadikov et al., 2000), S. viridiflora (Simon et al., 2009). S. viscidula (Xu et al., 2010 and 2012; Liao et al., 2013), S. cucubalus (Larhsini et al., 2003), and S. armeria (Takahashi et al., 2016). Most of them are based on oleanolic acid skeleton with $\mathrm{C}-23$ exhibiting different degrees of oxidation $\left(\mathrm{CH}_{3}, \mathrm{CHO}\right.$ or $\mathrm{COOH}$ ) and a hydroxyl group or a ketone group at C-16. A $\beta$-D-glucuronic acid linked to $\mathrm{C}-3$ and a $\beta$-D-fucose linked to C-28 of the aglycone, seems to be typical for this genus. For the first time, 
eleven previously undescribed triterpenoid saponins (1-11) were isolated from the aerial plant of Silene gallica L. These bisdesmosidic saponins contain saccharide moieties at C-3 and C-28 and their The aglycones were identified as caulophyllogenin $(3 \beta, 16 \alpha, 23$-trihydroxyolean-12-en-28-oic acid) for compounds 1-4, 7-11, echinocystic acid (3 $\beta, 16 \alpha$-dihydroxyolean-12-en-28-oic acid) for compound 5, and quillaic acid (3 $\beta, 16 \alpha$-dihydroxy-23-oxoolean-12-en-28-oic acid) for compound 6. The sugar moiety linked at C-3 was a $\beta$-D-glucuronic acid (1-11), substituted at C-3 by a $\beta$-Dgalactose in only for compounds 7-8 and 11. The other one linked to C-28 was determined as $\beta$-Dfucose substituted at C-2 by free or acylated $\beta$-D-glucoses at position 3 or 6 for all compounds. However, the fucose was substituted at C-3 by the glucose (1-2 and 4-8) or by the quinovose (9-11): Furtermore, according to the literature the present study confirms that saponins of Silene identified as $3 \beta, 16 \alpha$-dihydroxyolean-12-en-28-oic acid with different degrees of oxidation of $\mathrm{C}-23\left(\mathrm{CH}_{3}\right.$, $\mathrm{CH}_{2} \mathrm{OH}, \mathrm{CHO}, \mathrm{COOH}$ ) and linked at $\mathrm{C}-3$ by a $\beta$-D-glucuronic acid and at $\mathrm{C}-28$ by a $\beta$-D-fucose are the predominant saponin pattern, as far as they represent 46 compounds, including the herein decribed ones, among 63 of these specialized metabolites reported until now. Thus, they can be considered as a chemotaxonomic marker for the genus Silene. The unusual echinocystic and caulophyllogenin acids were previously reported in the Caryophyllaceae family (Böttger and Melzig, 2011; Koz at al., 2010; Timité et al., 2011). It is very interesting to note that saponins isolated from $S$. gallicaprovide new features with others types of aglycones such as caulophyllogenin and echinocystic, described for the first time in this genus. In addition, the presence, in our plant, of quinovose moiety attached to the $\beta$-D-fucose was peviously reported only from Silene rubicunda but it was linked at C-4 of the fucose (Wu et al., 2015). Compounds 9-11 with caulophyllogenin and quinovose moiety at C-3 of fucose could be considered as chemotaxomomic markers of this species.

\section{Experimental}

\subsection{General experimental procedures}


Optical rotations were measured in $\mathrm{MeOH}$ using a Perkin-Elmer 341 Polarimeter. ${ }^{1} \mathrm{H}-,{ }^{13} \mathrm{C}-\mathrm{NMR}$ and 2D-NMR measurements were recorded in $\mathrm{CD}_{3} \mathrm{OD}$ on a Bruker Avance III 600 spectrometer $\left({ }^{1} \mathrm{H}\right.$ at $600 \mathrm{MHz}$ and ${ }^{13} \mathrm{C}$ at $\left.150 \mathrm{MHz}\right)$ equipped with a $5 \mathrm{~mm}$ TCI cryoprobe. 2D-NMR experiments were performed using standard Bruker microprograms (TopSpin 3.5 software). HR-ESI-MS analysis was conducted using a Micromass Q-TOF micro instrument. Flash chromatography was carried out on a Grace Reveleris system equipped with dual UV and ELSD detection using Grace® cartridges (Silica gel or RP-C 18 ). HPLC separations were performed on a Dionex apparatus equipped with an ASI-100 autosampler, an Ultimate 3000 pump, a STH 585 column oven, a diode array detector UVD 340S and a Chromeleon software. A prepacked RP-C 18 column (Phenomenex $250 \times 10 \mathrm{~mm}$, Luna $5 \mu$ ) was used for semi-preparative HPLC. The eluting mobile phase consisted of $\mathrm{H}_{2} \mathrm{O}$ with TFA $(0.0025 \%)$ and $\mathrm{CH}_{3} \mathrm{CN}$ with a flow rate of $5 \mathrm{~mL} / \mathrm{min}$ and the chromatogram was monitored at 205 and $210 \mathrm{~nm}$. Thin-layer chromatography (TLC) was carried out using silica gel 60 $\mathrm{F}_{254}$ pre-coated aluminium plates $(0.2 \mathrm{~mm}$, Merck). After developing with solvent systems, spots were visualized by spraying with $50 \% \mathrm{H}_{2} \mathrm{SO}_{4}$ followed by heating.

\subsection{Plant material}

The aerial parts of Silene gallica were collected from Djebel El-Ouahch, Constantine (NorthEastern Algerian (GPS: $\mathrm{x}=6.671694, \mathrm{y}=36.394611, \mathrm{z}=888 \mathrm{~m}$ ) in May 2016, and identified by Mr. Kamel Kabouche. A voucher specimen (LOST Sg.05/16) has been deposited at the herbarium of LOST Laboratory, University frères Mentouri-Constantine, Algeria.

\subsection{Extraction and isolation}

The dried aerial part of $S$. gallica $(1 \mathrm{Kg})$ was macerated in $80 \% \mathrm{EtOH}(3 \times 5 \mathrm{~L}, 24 \mathrm{~h})$ at room temperature. After filtration, the solvent was removed under reduced pressure, the EtOH extract was diluted with $\mathrm{H}_{2} \mathrm{O}(700 \mathrm{~mL})$, then successively extracted with petroleum ether (PE), chloroform, ethyl acetate, and $n$-butanol $(3 \times 300 \mathrm{~mL}$, each). After evaporation of the solvents, $4 \mathrm{~g}$ of PE, $0.8 \mathrm{~g}$ of $\mathrm{CHCl}_{3}, 2.3 \mathrm{~g}$ of EtOAc and $33.2 \mathrm{~g}$ of $n-\mathrm{BuOH}$ extracts were obtained. A part of $n$-BuOH extract 
$(10.80 \mathrm{~g})$ was subjected to vacuum liquid chromatography over silica gel $(9 \mathrm{~cm} \times 5.5 \mathrm{~cm})$ eluted with the system $\mathrm{CH}_{2} \mathrm{Cl}_{2}-\mathrm{MeOH}-\mathrm{H}_{2} \mathrm{O}$ (95:5:0, 9:1:0, 8:2:0, 7:3:0, 7:3:0.5, 6:4:0.7, 1:1:0, 0:1:0) to obtain 8 fractions B1-B8, respectively. The combined fraction B6-7 (1.54 g) was fractionated by flash chromatography over silica gel, eluted by a gradient system of $20 \%$ to $50 \%$ of $\mathrm{MeOH}$ in $\mathrm{CH}_{2} \mathrm{Cl}_{2}$, in 40 min to afford 17 sub-fractions. Fraction B6-7-13 $(220 \mathrm{mg})$ was submitted to a flash chromatography over $\mathrm{RP}_{-} \mathrm{C}_{18}$, eluted by a gradient system of $20 \%-80 \% \mathrm{MeOH}$, in $30 \mathrm{~min}$. Subfractions B6-7-13[46-50] (18.9 mg) was purified by semi-prep. HPLC using a gradient (30-50\% $\mathrm{CH}_{3} \mathrm{CN}$, in $\left.15 \mathrm{~min}\right)$ to give compounds $3\left(1.5 \mathrm{mg}, t_{\mathrm{R}} 8.5 \mathrm{~min}\right)$ and $6\left(1.5 \mathrm{mg}, t_{\mathrm{R}} 7.8 \mathrm{~min}\right)$ whereas the purification of the B6-7-13[55-60] $\left(24 \mathrm{mg}\right.$ ) in the same condition gave compounds 5 (3.6 $\mathrm{mg}, t_{\mathrm{R}} 8.7$ min) and 9 (6.9 mg, $\left.t_{\mathrm{R}} 10.1 \mathrm{~min}\right)$. Fraction B6-7-14 (158 mg) was flash chromatographed over RPC18, eluted with $\mathrm{MeOH}: \mathrm{H}_{2} \mathrm{O}$ (35\%-80\% MeOH, in 24 min). Sub-fraction B6-7-14[15-16] (35 mg) was purified by semi-prep HPLC eluted by gradient system $30 \%-43 \% \mathrm{CH}_{3} \mathrm{CN}$, in 15 min to yield compound 2 (4.6 $\left.\mathrm{mg}, t_{\mathrm{R}} 7.3 \mathrm{~min}\right)$. The purification by semi-prep HPLC of B6-7-16 $(80 \mathrm{mg}) \mathrm{using}$ a gradient from $30 \%$ to $45 \% \mathrm{CH}_{3} \mathrm{CN}$, in $20 \mathrm{~min}$ led to compound 4 (9.1 mg, $\left.t_{\mathrm{R}} 11.4 \mathrm{~min}\right)$. Fraction B6-7-17 (288 mg) was submitted to a flash chromatography over RP-C 18 , eluted by a gradient system of $20-80 \% \mathrm{MeOH}$, in $30 \mathrm{~min}$. Sub-fraction B6-7-17[56-60] (35 mg) was purified by semi-prep HPLC using a gradient from $30 \%$ to $45 \% \mathrm{CH}_{3} \mathrm{CN}$, in $15 \mathrm{~min}$, to afford compounds 1 (11.2 $\mathrm{mg}, t_{\mathrm{R}}$ $7.6 \mathrm{~min}), 7\left(1.6 \mathrm{mg}, t_{\mathrm{R}} 6.8 \mathrm{~min}\right)$ and $8\left(2.9 \mathrm{mg}, t_{\mathrm{R}} 9.2 \mathrm{~min}\right)$. Sub-fraction B6-7-17[66-78] (43 $\left.\mathrm{mg}\right)$ was also purified by semi-prep HPLC using a gradient from $30 \%$ to $45 \% \mathrm{CH}_{3} \mathrm{CN}$, in 15 min, to yield compounds 10 (6.5 mg, $\left.t_{\mathrm{R}} 11.0 \mathrm{~min}\right)$ and $\mathbf{1 1}\left(1.8 \mathrm{mg}, t_{\mathrm{R}} 10.6 \mathrm{~min}\right)$.

\subsubsection{Silenegallisaponin A (1)}

Amorphous white powder; $[\alpha]_{D}^{25}-9.4(c 0.93, \mathrm{MeOH}) ;{ }^{1} \mathrm{H}\left(600 \mathrm{MHz}, \mathrm{CD}_{3} \mathrm{OD}\right)$ and ${ }^{13} \mathrm{C} \mathrm{NMR}(150$ $\mathrm{MHz}, \mathrm{CD}_{3} \mathrm{OD}$ ) data; see Tables 1 and 2. HR-ESI-MS $\mathrm{m} / \mathrm{z} 1157.5367[\mathrm{M}+\mathrm{Na}]^{+}$(calcd for $\left.\mathrm{C}_{54} \mathrm{H}_{86} \mathrm{O}_{25} \mathrm{Na}, 1157.5356\right)$. 


\subsubsection{Silenegallisaponin B (2)}

Amorphous white powder; $[\alpha]_{D}^{25}-9.2(c 0.38, \mathrm{MeOH}) ;{ }^{1} \mathrm{H}\left(600 \mathrm{MHz}, \mathrm{CD}_{3} \mathrm{OD}\right)$ and ${ }^{13} \mathrm{C} \mathrm{NMR}(150$ $\mathrm{MHz}, \mathrm{CD}_{3} \mathrm{OD}$ ) data; see Tables 1 and 2. HR-ESI-MS $\mathrm{m} / \mathrm{z} 1199.5454[\mathrm{M}+\mathrm{Na}]^{+}$(calcd for $\left.\mathrm{C}_{56} \mathrm{H}_{88} \mathrm{O}_{26} \mathrm{Na}, 1199.5462\right)$.

\subsubsection{Silenegallisaponin C (3)}

Amorphous white powder; $[\alpha]_{D}^{25}-13.3(c 0.12, \mathrm{MeOH}) ;{ }^{1} \mathrm{H}\left(600 \mathrm{MHz}, \mathrm{CD}_{3} \mathrm{OD}\right)$ and ${ }^{13} \mathrm{C} \mathrm{NMR}(150$ $\mathrm{MHz}, \mathrm{CD}_{3} \mathrm{OD}$ ) data; see Tables 1and 2. HR-ESI-MS $m / z \quad 1037.4926[\mathrm{M}+\mathrm{Na}]^{+}$(calcd for $\left.\mathrm{C}_{50} \mathrm{H}_{78} \mathrm{O}_{21} \mathrm{Na}, 1037.4933\right)$.

\subsubsection{Silenegallisaponin D (4)}

Amorphous white powder; $[\alpha]_{D}^{25}-10.7\left(c\right.$ 0.75, MeOH); ${ }^{1} \mathrm{H}\left(600 \mathrm{MHz}, \mathrm{CD}_{3} \mathrm{OD}\right)$ and ${ }^{13} \mathrm{C} \mathrm{NMR}(150$ $\mathrm{MHz}, \mathrm{CD}_{3} \mathrm{OD}$ ) data; see Tables 1 and 2. HR-ESI-MS $\mathrm{m} / \mathrm{z} 1199.5455[\mathrm{M}+\mathrm{Na}]^{+}$(calcd for $\left.\mathrm{C}_{56} \mathrm{H}_{88} \mathrm{O}_{26} \mathrm{Na}, 1199.5462\right)$.

\subsubsection{Silenegallisaponin E (5)}

Amorphous white powder; $[\alpha]_{D}^{25}-7.7(c 0.3, \mathrm{MeOH}) ;{ }^{1} \mathrm{H}\left(600 \mathrm{MHz}, \mathrm{CD}_{3} \mathrm{OD}\right)$ and ${ }^{13} \mathrm{C} \mathrm{NMR}(150$ $\mathrm{MHz}, \mathrm{CD}_{3} \mathrm{OD}$ ) data; see Tables 1 and 2. HR-ESI-MS $\mathrm{m} / \mathrm{z} 1183.5502[\mathrm{M}+\mathrm{Na}]^{+}$(calcd for $\mathrm{C}_{56} \mathrm{H}_{88} \mathrm{O}_{25} \mathrm{Na}$, 1183.5512).4.3.6. Silenegallisaponin F (6)

Amorphous white powder; $[\alpha]_{D}^{25}-5$ (c 0.12, MeOH); ${ }^{1} \mathrm{H}\left(600 \mathrm{MHz}, \mathrm{CD}_{3} \mathrm{OD}\right)$ and ${ }^{13} \mathrm{C} \mathrm{NMR}(150$ $\mathrm{MHz}, \mathrm{CD}_{3} \mathrm{OD}$ ) data; see Tables 1 and 2. HR-ESI-MS $\mathrm{m} / z \quad 1197.5298[\mathrm{M}+\mathrm{Na}]^{+}$(calcd for $\left.\mathrm{C}_{56} \mathrm{H}_{86} \mathrm{O}_{26} \mathrm{Na}, 1197.5305\right)$.

\subsubsection{Silenegallisaponin $G(7)$}


Amorphous white powder; $[\alpha]_{D}^{25}-6-13.1(c$ 0.13, MeOH $) ;{ }^{1} \mathrm{H}\left(600 \mathrm{MHz}, \mathrm{CD}_{3} \mathrm{OD}\right)$ and ${ }^{13} \mathrm{C} \mathrm{NMR}$ (150 MHz, $\mathrm{CD}_{3} \mathrm{OD}$ ) data; see Tables 3 and 4. HR-ESI-MS $\mathrm{m} / \mathrm{z} 1319.5870 \quad[\mathrm{M}+\mathrm{Na}]^{+}$(calcd for $\left.\mathrm{C}_{60} \mathrm{H}_{96} \mathrm{O}_{30} \mathrm{Na}, 1319.5884\right)$.

\subsubsection{Silenegallisaponin $H(8)$}

Amorphous white powder; $[\alpha]_{D}^{25}-7.5(c 0.24, \mathrm{MeOH}) ;{ }^{1} \mathrm{H}\left(600 \mathrm{MHz}, \mathrm{CD}_{3} \mathrm{OD}\right)$ and ${ }^{13} \mathrm{C} \mathrm{NMR}(150$ $\mathrm{MHz}, \mathrm{CD}_{3} \mathrm{OD}$ ) data; see Tables 3 and 4. HR-ESI-MS $\mathrm{m} / \mathrm{z} 1361.5981[\mathrm{M}+\mathrm{Na}]^{+}$(calcd for $\left.\mathrm{C}_{62} \mathrm{H}_{98} \mathrm{O}_{31} \mathrm{Na}, 1361.5990\right)$.

\subsubsection{Silenegallisaponin I (9)}

Amorphous white powder; $[\alpha]_{D}^{25}-10.2(c 0.57, \mathrm{MeOH}) ;{ }^{1} \mathrm{H}\left(600 \mathrm{MHz}, \mathrm{CD}_{3} \mathrm{OD}\right)$ and ${ }^{13} \mathrm{C} \mathrm{NMR}(150$ $\mathrm{MHz}, \mathrm{CD}_{3} \mathrm{OD}$ ) data; see Tables 3 and 4. HR-ESI-MS $\mathrm{m} / \mathrm{z} 1183.5503[\mathrm{M}+\mathrm{Na}]^{+}$(calcd for $\left.\mathrm{C}_{56} \mathrm{H}_{88} \mathrm{O}_{25} \mathrm{Na}, 1183.5512\right)$.

\subsubsection{Silenegallisaponin J (10)}

Amorphous white powder; $[\alpha]_{D}^{25}-9.6(c 0.54, \mathrm{MeOH}) ;{ }^{1} \mathrm{H}\left(600 \mathrm{MHz}, \mathrm{CD}_{3} \mathrm{OD}\right)$ and ${ }^{13} \mathrm{C} \mathrm{NMR}(150$ $\mathrm{MHz}, \mathrm{CD}_{3} \mathrm{OD}$ ) data; see Tables 3 and 4. HR-ESI-MS $\mathrm{m} / \mathrm{z} 1141.5413[\mathrm{M}+\mathrm{Na}]^{+}$(calcd for $\left.\mathrm{C}_{54} \mathrm{H}_{86} \mathrm{O}_{24} \mathrm{Na}, 1141.5407\right)$.

\subsubsection{Silenegallisaponin $K(11)$}

Amorphous white powder; $[\alpha]_{D}^{25}-7.3(c 0.15, \mathrm{MeOH}) ;{ }^{1} \mathrm{H}\left(600 \mathrm{MHz}, \mathrm{CD}_{3} \mathrm{OD}\right)$ and ${ }^{13} \mathrm{C} \mathrm{NMR}(150$ $\mathrm{MHz}, \mathrm{CD}_{3} \mathrm{OD}$ ) data; see Tables 3 and 4. HR-ESI-MS $\mathrm{m} / \mathrm{z} 1303.5925[\mathrm{M}+\mathrm{Na}]^{+}$(calcd for $\left.\mathrm{C}_{60} \mathrm{H}_{96} \mathrm{O}_{29} \mathrm{Na}, 1303.5935\right)$.

\subsection{Acid hydrolysis}


An aliquot of the saponin-containing fraction (100 mg of fraction B6-B7) was treated with 2 N TFA (trifluoroacetic acid, aqueous solution, $15 \mathrm{~mL})$ at $90{ }^{\circ} \mathrm{C}$ for $6 \mathrm{~h}$. After extraction with $\mathrm{CH}_{2} \mathrm{Cl}_{2}(10$ $\mathrm{mL} \times 3)$, the water-soluble layer was evaporated to dryness $(56.7 \mathrm{mg})$. The sugars were first analyzed by TLC over silica gel $\left(\mathrm{CH}_{3} \mathrm{COOEt}: \mathrm{CH}_{3} \mathrm{COOH}: \mathrm{CH}_{3} \mathrm{OH}: \mathrm{H}_{2} \mathrm{O}, 65: 25: 15: 15\right)$. The sample was purified by preparative Si gel TLC using the same eluent as for the standards to afford glucose [14 mg, $\left.R_{\mathrm{f}}=0.48\right]$, galactose [ $\left.4 \mathrm{mg}, R_{\mathrm{f}}=0.43\right]$, fucose [3.5 mg, $\left.R_{\mathrm{f}}=0.52\right]$, quinovose [2.0 $\mathrm{mg}, R_{\mathrm{f}}=$ 0.62], and glucuronic acid [1.8 $\left.\mathrm{mg}, R_{\mathrm{f}}=0.10\right](1,8 \mathrm{mg})$. The absolute configurations of these sugars were determined as D by measurement of the optical rotation of each purified monosaccharide.

\section{Supporting Information}

HR-ESI-MS and 1D and 2D NMR spectra of 1-11

\section{Acknowledgements.}

The authors are grateful to MESRS Algeria for the Profas grant to Ms Sara Bechkri, to CNRS, Conseil Regional Champagne Ardenne, Conseil General de la Marne, Ministry of Higher Education and Research (MESR) in France, and to the PIANET CPER project for financial support.

\section{References}

Agrawal, P.K., 1992. NMR Spectroscopy in the structural elucidation of oligosaccharides and glycosides. Phytochemistry 31, 3307-3330.

Alabdul Magid, A., Voutquenne-Nazabadioko, L., Renimel, I., Harakat, D., Moretti, C., Lavaud, C., 2006. Triterpenoid saponins from the stem bark of Caryocar villosum. Phytochemistry 67, 2096-2102.

Arnetoli, M., Montegrossi, G., Buccianti, A., Gonnelli, C., 2008. Determination of organic acids in plants of Silene paradoxa L. by HPLC. J. Agric. Food Chem. 56, 789-795.

Asai, T., Fujimoto, Y., 2010. Cyclic fatty acyl glycosides in the glandular trichome exudate of Silene gallica. Phytochemistry 71, 1410-1417. 
Böttger, S., Melzig, M.F., 2011. Triterpenoid saponins of the Caryophyllaceae and Illecebraceae family. Phytochem. Lett. 4, 59-68.

Bouguet-Bonnet, S., Rochd, M., Mutzenhardt, P., Henry, M., 2002. Total assignment of ${ }^{1} \mathrm{H}$ and ${ }^{13} \mathrm{C}$ NMR spectra of three triterpene saponins from roots of Silene vulgaris (Moench) Garcke. Magn. Reson. Chem. 40, 618-621.

Boutaghane, N., Voutquenne-Nazabadioko, L., Harkat, D., Simon, A., Kabouche, Z., 2013. Triterpenoid saponins of Genista ulcina Spach. Phytochemistry 93, 176-181.

Boutaghane, N., Alabdul Magid, A., Abedini A., Cafolla, A., Djeghim, H., Gangloff, S.C., Voutquenne-Nazabadioko, L., Kabouche, Z., 2019. Chemical constituents of Genista numidica Spach aerial parts and their antimicrobial, antioxidant and antityrosinase activities. Nat. Prod. Res. 33, 1734-1740.

Darmograi, V., 1977. Flavonoids of plants of the genera Silene and Otites adans, family Caryophyllaceae. Chem. Nat. Compd. 13, 102-103.

Dötterl, S., Wolfe, L.M., Jürgens, A., 2005. Qualitative and quantitative analyses of flower scent in Silene latifolia. Phytochemistry 66, 203-213.

Eshmirzaeva, N.E., Khidyrova, N.K., Khodzhaeva, M., Mezhlumyan, L.G., Shakhidoyatov, K.M., 2005. Chemical Composition of Silene viridiflora. Chem. Nat. Compd. 41, 451-453.

Gaidi, G., Miyamoto, T., Laurens, V., Lacaille-Dubois, M.A., 2002. New acylated triterpene saponins from Silene fortunei that modulate lymphocyte proliferation. J. Nat. Prod. 65, 15681572.

Glensk, M., Wray, V., Nimtz, M., Schöpke, T., 1999. Silenosides A-C, triterpenoid saponins from Silene vulgaris. J. Nat. Prod. 62, 717-721.

Fu, H., Koike, K., Li, W., Nikaido, T., Lin, W., Guo, D., 2005. Silenorubicosides A-D, triterpenoid saponins from Silene rubicunda. J. Nat. Prod. 68, 754-758.

Lacaille-Dubois, M.A., Hanquet, B., Cui, Z.H., Lou, Z.C., Wagner, H., 1995. Acylated triterpene saponins from Silene jenisseensis. Phytochemistry 40, 509-514. 
Lacaille-Dubois, M.A., Hanquet, B., Cui, Z.H., Lou, Z.C., Wagner, H., 1997. Jenisseensosides C and D, biologically active acylated triterpene saponins from Silene jenisseensis. Phytochemistry 45, 985-990.

Lacaille-Dubois, M.A., Hanquet, B., Cui, Z.H., Lou, Z.C., Wagner, H., 1999. A new biologically active acylated triterpene saponin from Silene fortunei. J. Nat. Prod. 62, 133-136.

Larhsini, M., Marston, A., Hostettmann, K., 2003. Triterpenoid saponins from the roots of Silene cucubalus. Fitoterapia 74, 237-241.

Lehbili, M., Alabdul Magid, A., Kabouche, A., Voutquenne-Nazabadioko, L., Abedini, A., Morjani, H., Sarazin, T., Morjani, H., Gangloff, S.C., Kabouche, Z., 2017. Oleanane-type triterpene saponins from Calendula stellata. Phytochemistry 144, 33-42.

Lehbili, M., Alabdul Magid, A., Kabouche, A., Voutquenne-Nazabadioko, L., Morjani, H., Harkat, D., Kabouche, Z., 2018. Triterpenoid saponins from Scabiosa stelatta collected in the Northeastern Algeria. Phytochemistry 150, 40-49.

Liao, C., Zhao, B., Wang, X., Liu, C., Xu, G., Liu, S., Zhang, X., Wang, X., 2013. Isolation and characterization of chemical constituents from the roots of Silene viscidula Franch. Asian J. Chem. 25, 10311-10314.

Mamadalieva, N.Z., Lafont, R., Wink, M., 2014. Diversity of secondary metabolites in the genus Silene L. (Caryophyllaceae)-Structures, distribution, and biological properties. Diversity 6, 415-499.

Matsuo,Y., Watanabe, K., Mimaki, Y., 2009. Triterpene glycosides from the underground parts of Caulophyllum thalictroides. J. Nat. Prod. 72, 1155-1160.

Pertuit, D., Avunduk, S., Mitaine-Offer, A.C., Miyamoto, T., Tanaka, C., Paululat, T., Delemasure, S., Dutartre, P., Lacaille-Dubois, M.A., 2014. Triterpenoid saponins from the roots of two Gypsophila species. Phytochemistry 102, 182-188.

Sadikov, Z.T., Saatov, Z., Girault, J.P., Lafont, R., 2000. Sileneoside H, a New Phytoecdysteroid from Silene brahuica. J. Nat. Prod. 63, 987-988. 
Simon, A., Toth, N., Gabor, K., Zoltan, G., Groska, J., Bathori, M., 2009. Ecdysteroids from Silene viridiflora. Helv. Chim. Acta 92, 753-761.

Takahashi, N., Li, W., Koike, K., 2016. Oleanane-type triterpenoid saponins from Silene armeria. Phytochemistry 129, 77-85.

Tan, N., Zhou, J., Zhao, S., Cheng, C., 1996. Rubicunosides B, C, D-three new triterpenoids saponins with acetylated saccharides from Silene rubicunda. Acta. Chim. Sin. 54, 722-728.

Timité, G., Mitaine-Offer, A.C., Miyamoto, T., Tanaka, C., Mirjolet, J.F., Duchamp, O., LacailleDubois, M.A., 2011. Unusual oleanane-type saponins from Arenaria montana. Phytochemistry 72, 503-507.

Voutquenne-Nazabadioko, L., Gevrenova, R., Borie, N., Harakat, D., Sayagh, C., Weng, A., Thakur, M., Zaharieva, M., Henry, M., 2013. Triterpenoid saponins from the roots of Gypsophila trichotoma Wender. Phytochemistry 90, 114-127.

Wu, Q., Tu, G.Z., Fu, H.Z., 2014. A new triterpenoid saponin from Silene rubicunda Franch. J. Chin. Pharm. Sci. 23, 246-250.

Wu, Q., Tu, G.Z., Fu, H.Z., 2015. Silenorubicoside E-I, five new triterpenoid saponins isolated from Silene rubicunda Franch. Mag. Reson. Chem. 53, 544-550.

Xu, W., Wu, J., Zhu, Z., Sha, Y., Fang, J., Li, Y., 2010. Pentacyclic triterpenoid saponins from Silene viscidula. Helv. Chim. Acta 93, 2007-2014.

Xu,W., Fang, J., Zhu, Z.,Wu, J., Li, Y., 2012. A new triterpenoid saponin from the roots of Silene viscidula. Nat. Prod. Res. 26, 2002-2007. 


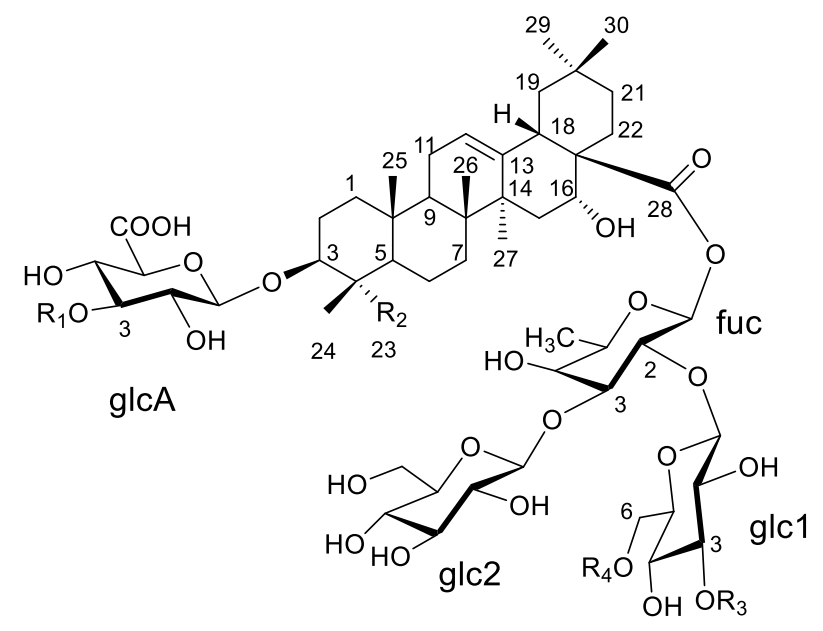

$\begin{array}{lllll} & \mathbf{R}_{\mathbf{1}} & \mathbf{R}_{\mathbf{2}} & \mathbf{R}_{\mathbf{3}} & \mathbf{R}_{\mathbf{4}} \\ \mathbf{1} & \mathrm{H} & \mathrm{CH}_{2} \mathrm{OH} & \mathrm{H} & \mathrm{H} \\ \mathbf{2} & \mathrm{H} & \mathrm{CH}_{2} \mathrm{OH} & \mathrm{Ac} & \mathrm{H} \\ \mathbf{4} & \mathrm{H} & \mathrm{CH}_{2} \mathrm{OH} & \mathrm{H} & \mathrm{Ac} \\ \mathbf{5} & \mathrm{H} & \mathrm{CH}_{3} & \mathrm{Ac} & \mathrm{H} \\ \mathbf{6} & \mathrm{H} & \mathrm{CHO} & \mathrm{Ac} & \mathrm{H} \\ \mathbf{7} & \text { gal } & \mathrm{CH}_{2} \mathrm{OH} & \mathrm{H} & \mathrm{H} \\ \mathbf{8} & \text { gal } & \mathrm{CH}_{2} \mathrm{OH} & \mathrm{H} & \mathrm{Ac}\end{array}$

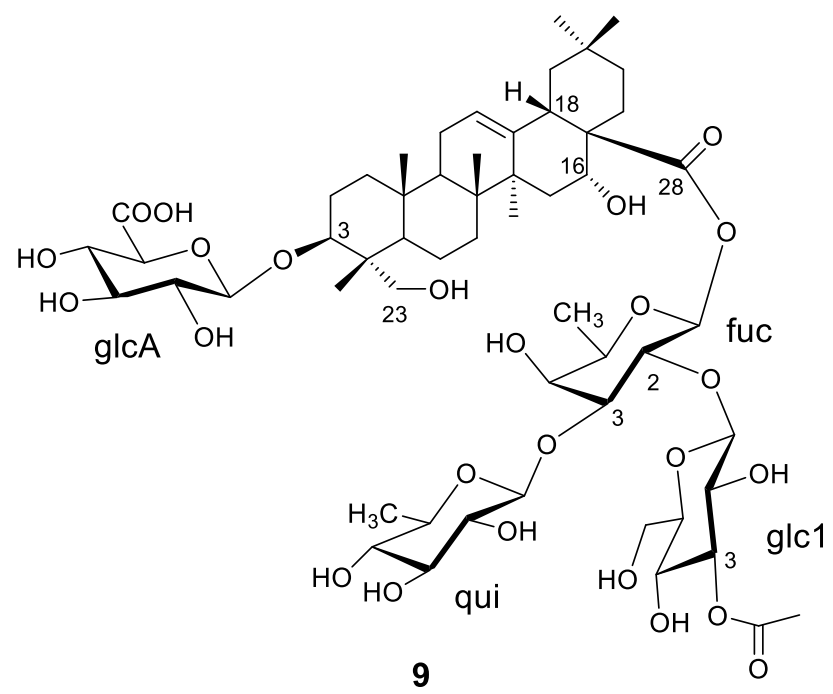

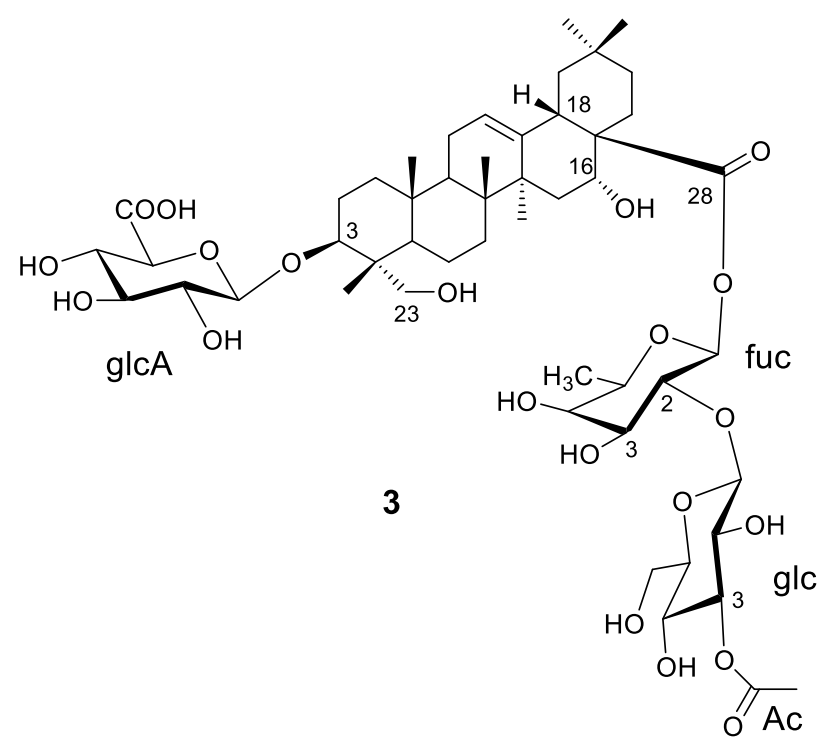

gal =

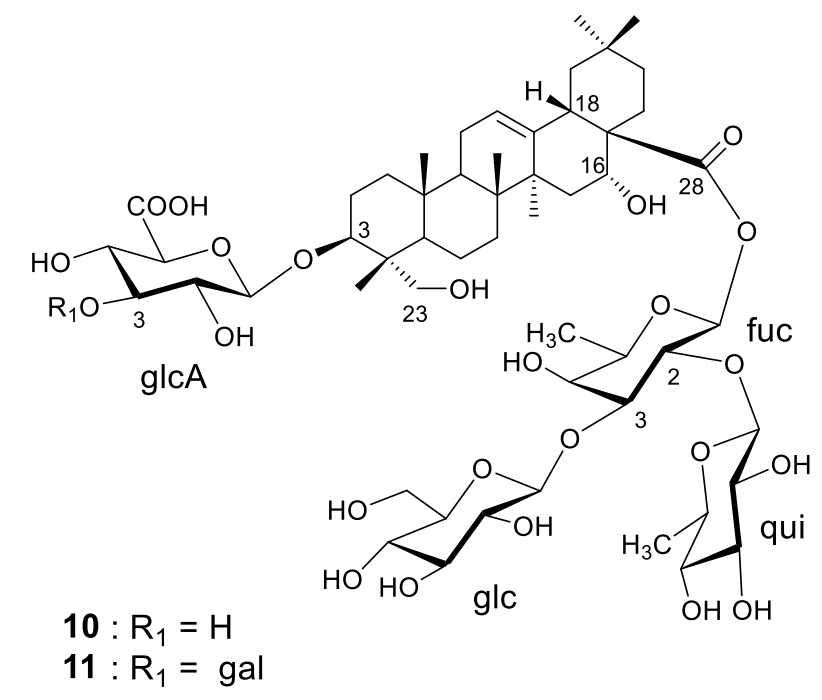

Fig. 1. Chemical structures of compounds 1-11 isolated from Silene gallica. 
Table 1

${ }^{13} \mathrm{C}$ NMR and ${ }^{1} \mathrm{H}$ NMR spectroscopic data of the aglycone moieties of compounds $\mathbf{1}-\mathbf{6}$ in $\mathrm{CD}_{3} \mathrm{OD} .{ }^{\mathbf{a}, \mathbf{b}}$

\begin{tabular}{|c|c|c|c|c|c|c|c|c|c|c|c|c|}
\hline & \multicolumn{2}{|r|}{1} & \multicolumn{2}{|r|}{2} & \multicolumn{2}{|r|}{3} & \multicolumn{2}{|r|}{4} & \multicolumn{2}{|r|}{5} & \multicolumn{2}{|r|}{6} \\
\hline \multirow{3}{*}{1} & $\delta_{\mathrm{C}}$ & $\delta_{\mathrm{H}}$ & $\delta_{\mathrm{C}}$ & $\delta_{\mathrm{H}}$ & $\delta_{\mathrm{C}}$ & $\delta_{\mathrm{H}}$ & $\delta_{\mathrm{C}}$ & $\delta_{\mathrm{H}}$ & $\delta_{\mathrm{C}}$ & $\delta_{\mathrm{H}}$ & $\delta_{\mathrm{C}}$ & $\delta_{\mathrm{H}}$ \\
\hline & 38.2 & $1.01, \mathrm{~m}$ & 38.2 & $1.02, \mathrm{~m}$ & 38.2 & $1.02, \mathrm{~m}$ & 38.1 & $1.00, \mathrm{~m}$ & 38.4 & $1.03, \mathrm{~m}$ & 37.8 & $1.18, \mathrm{~m}$ \\
\hline & & 1.65 & & $1.63, \mathrm{~m}$ & & $1.64, \mathrm{~m}$ & & $1.64, \mathrm{~m}$ & & 1.63 & & $1.71, \operatorname{td}(13.6,3.4)$ \\
\hline \multirow[t]{2}{*}{2} & 25.0 & 1.78 & 24.9 & $1.78, \mathrm{~m}$ & 24.9 & $1.78, \mathrm{~m}$ & 25.0 & $1.76, \mathrm{~m}$ & 25.6 & $1.72, \mathrm{~m}$ & 24.2 & 1.80 \\
\hline & & 1.89 & & $1.97, \mathrm{~m}$ & & 1.98 & & 1.91 & & 1.90 & & 2.04 \\
\hline 3 & 82.0 & $3.66, \mathrm{dd}(12.5,5.0)$ & 81.0 & $3.67, \mathrm{dd}(11.5,4.7)$ & 81.0 & $3.69, \mathrm{dd}(12.1,4.3)$ & 81.9 & $3.67, \mathrm{dd}(12.0,4.3)$ & 89.6 & $3.20, \mathrm{dd}(11.7,4.3)$ & 81.3 & $3.98, \mathrm{dd}(11.7,4.3)$ \\
\hline 4 & 42.5 & - & 42.5 & - & 42.5 & - & 42.5 & - & 38.8 & - & 55.0 & - \\
\hline 5 & 46.8 & 1.26 & 46.8 & 1.28 & 46.9 & 1.28, br d (12.9) & 46.9 & 1.27 & 55.7 & 0.82, br d (12.3) & 47.4 & 1.38 \\
\hline \multirow[t]{2}{*}{6} & 17.4 & 1.39 & 17.5 & $1.42, \operatorname{td}(12.1,3.6)$ & 17.6 & $1.43, \operatorname{td}(12.5,3.5)$ & 17.5 & 1.40 & 18.0 & $1.46, \operatorname{td}(12.3,3.5)$ & 20.0 & 0.98 \\
\hline & & 1.51 & & 1.52, br d (12.3) & & 1.55, br d (11.5) & & $1.52, \mathrm{~m}$ & & 1.60 & & 1.59 \\
\hline \multirow[t]{2}{*}{7} & 32.4 & 1.33 & 32.4 & 1.33 & 32.3 & $1.37, \mathrm{~m}$ & 32.4 & 1.32 & 33.0 & $1.39, \mathrm{~m}$ & 32.2 & 1.32 \\
\hline & & 1.68 & & 1.68 & & 1.68 & & 1.68 & & $1.56, \operatorname{td}(12.5,3.3)$ & & $1.58, \mathrm{~m}$ \\
\hline 8 & 39.5 & - & 39.5 & - & 39.5 & - & 39.5 & - & 39.5 & - & 39.8 & - \\
\hline 9 & 46.8 & 1.70 & 46.9 & 1.72, br t $(9.3)$ & 46.8 & $1.73, \mathrm{t}(13.3)$ & 46.8 & 1.72, br t (10.0) & 46.8 & $1.68, \operatorname{brt}(9.3)$ & 46.7 & 1.80 \\
\hline 10 & 36.3 & - & 36.3 & - & 36.3 & - & 36.3 & - & 36.5 & - & 35.6 & - \\
\hline \multirow{2}{*}{11} & 23.1 & 1.91 & 23.1 & 1.91 & 23.1 & 1.90 & 23.1 & 1.89 & 23.1 & 1.91 & 23.0 & 1.95 \\
\hline & & 1.93 & & 1.93 & & 1.92 & & 1.91 & & 1.93 & & 1.97 \\
\hline 12 & 121.9 & $5.32, \mathrm{t}(3.7)$ & 121.9 & $5.32, \mathrm{t}(3.3)$ & 122.0 & $5.32, \mathrm{t}(3.5)$ & 122.0 & $5.31, \mathrm{t}(3.5)$ & 122.0 & $5.32, \mathrm{t}(3.1)$ & 121.7 & $5.33, \mathrm{t}(3.5)$ \\
\hline 13 & 143.5 & - & 143.5 & - & 143.4 & - & 143.7 & - & 143.5 & - & 143.6 & - \\
\hline 14 & 41.2 & - & 41.1 & - & 41.2 & - & 41.2 & - & 41.1 & - & 41.1 & - \\
\hline \multirow[t]{2}{*}{15} & 35.5 & 1.32 & 35.7 & 1.33 & 35.6 & 1.35 & 35.4 & 1.33 & 35.7 & 1.32 & 35.8 & 1.31 \\
\hline & & 1.79 & & 1.80 & & $1.81, \mathrm{dd}(14.5,3.5)$ & & 1.93 & & $1.80, \mathrm{dd}(15.0,3.6)$ & & 1.79 \\
\hline 16 & 72.7 & $4.78, \mathrm{t}(3.5)$ & 72.7 & $4.78, \mathrm{t}(3.4)$ & 72.8 & $4.72, \mathrm{t}(3.5)$ & 73.1 & $4.62, \mathrm{br} \mathrm{s}$ & 72.7 & $4.78, \mathrm{t}(3.5)$ & 72.7 & 4.77, br s \\
\hline 17 & 48.6 & - & 48.5 & - & 48.4 & - & 47.5 & - & 48.5 & - & 47.5 & - \\
\hline 18 & 40.6 & $2.98, \mathrm{dd}(14.3,4.0)$ & 40.5 & $2.99, \mathrm{dd}(14.5,4.2)$ & 40.6 & $2.99, \mathrm{dd}(14.4,4.0)$ & 40.5 & $2.99, \mathrm{dd}(13.5,4.2)$ & 40.5 & $2.99, \mathrm{dd}(14.4,4.1)$ & 40.4 & $2.99, \mathrm{dd}(13.3,4.0)$ \\
\hline \multirow[t]{2}{*}{19} & 46.3 & $1.08, \mathrm{dd}(12.7,3.2)$ & 46.3 & $1.08, \mathrm{dd}(13.0,3.1)$ & 46.3 & $1.08, \mathrm{dd}(14.1,3.6)$ & 46.3 & $1.05, \mathrm{~m}$ & 46.3 & $1.08, \mathrm{~m}$ & 46.2 & $1.09, \mathrm{dd}(13.3,5.2)$ \\
\hline & & $2.28, \mathrm{t}(13.8)$ & & $2.27, \mathrm{t}(13.4)$ & & $2.26, \mathrm{t}(14.1)$ & & 2.30, br t (13.5) & & $2.27, \mathrm{t}(13.9)$ & & $2.28, \mathrm{t}(13.5)$ \\
\hline 20 & 30.0 & - & 29.9 & - & 29.9 & - & 29.9 & - & 29.9 & - & 29.9 & - \\
\hline \multirow{2}{*}{21} & 35.0 & $1.16, \mathrm{~m}$ & 35.0 & 1.16, br d (12.7) & 34.9 & $1.17, \mathrm{~m}$ & 35.1 & $1.16, \mathrm{~m}$ & 35.0 & $1.16, \mathrm{~m}$ & 35.0 & 1.18 \\
\hline & & 1.91 & & 1.92 & & 1.91 & & 1.91 & & 1.93 & & 1.95 \\
\hline \multirow[t]{2}{*}{22} & 29.9 & 1.70 & 30.0 & 1.70 & 29.9 & 1.71 & 30.7 & 1.69 & 29.9 & 1.69 & 30.3 & $1.69, \operatorname{td}(13.5,3.7)$ \\
\hline & & $2.01, \mathrm{dt}(14.0,3.7)$ & & $2.02, \mathrm{dt}(13.8,3.9)$ & & 2.00 & & 1.94 & & $2.02, \operatorname{tddt}(13.2,3.5)$ & & $2.01, \mathrm{~m}$ \\
\hline \multirow[t]{2}{*}{23} & 63.3 & $3.29, \mathrm{~d}(11.5)$ & 63.4 & $3.28, \mathrm{~d}(11.7)$ & 63.4 & $3.24, \mathrm{~d}(11.7)$ & 63.4 & $3.30, \mathrm{~d}(12.0)$ & 27.1 & $1.08, \mathrm{~s}$ & 207.5 & $9.44, \mathrm{~s}$ \\
\hline & & $3.63, \mathrm{~d}(11.5)$ & & $3.65, \mathrm{~d}(11.7)$ & & $3.64, \mathrm{~d}(11.7)$ & & $3.64, \mathrm{~d}(12.0)$ & & & & \\
\hline 24 & 12.0 & $0.72, \mathrm{~s}$ & 12.1 & $0.79, \mathrm{~s}$ & 12.1 & $0.72, \mathrm{~s}$ & 12.0 & $0.73, \mathrm{~s}$ & 15.6 & $0.88, \mathrm{~s}$ & 8.9 & $1.12, \mathrm{~s}$ \\
\hline 25 & 15.2 & $1.02, \mathrm{~s}$ & 15.2 & $1.01, \mathrm{~s}$ & 15.2 & $1.01, \mathrm{~s}$ & 15.2 & $1.02, \mathrm{~s}$ & 14.7 & $0.98, \mathrm{~s}$ & 14.8 & $1.03, \mathrm{~s}$ \\
\hline 26 & 16.5 & $0.79, \mathrm{~s}$ & 16.6 & $0.79, \mathrm{~s}$ & 16.6 & $0.80, \mathrm{~s}$ & 16.5 & $0.78, \mathrm{~s}$ & 16.5 & $0.79, \mathrm{~s}$ & 16.4 & $0.79, \mathrm{~s}$ \\
\hline 27 & 26.0 & $1.37, \mathrm{~s}$ & 26.0 & $1.38, \mathrm{~s}$ & 26.0 & $1.38, \mathrm{~s}$ & 25.9 & $1.40, \mathrm{~s}$ & 25.9 & $1.37, \mathrm{~s}$ & 25.9 & $1.39, \mathrm{~s}$ \\
\hline 28 & 175.7 & - & 175.6 & - & 175.7 & - & 175.7 & - & 175.6 & - & 175.5 & - \\
\hline 29 & 31.9 & $0.91, \mathrm{~s}$ & 31.9 & $0.91, \mathrm{~s}$ & 31.9 & $0.91, \mathrm{~s}$ & 31.9 & $0.91, \mathrm{~s}$ & 31.9 & $0.91, \mathrm{~s}$ & 31.9 & $0.91, \mathrm{~s}$ \\
\hline 30 & 23.7 & $0.97, \mathrm{~s}$ & 23.7 & $0.97, \mathrm{~s}$ & 23.8 & $0.97, \mathrm{~s}$ & 23.5 & $0.97, \mathrm{~s}$ & 23.6 & $0.97, \mathrm{~s}$ & 23.5 & $0.97, \mathrm{~s}$ \\
\hline
\end{tabular}

a Overlapped signals are reported without designated multiplicity.

${ }^{\mathrm{b}}$ in $\mathrm{ppm}, J$ in parentheses in $\mathrm{Hz}$. 


\section{Table 2}

${ }^{13} \mathrm{C}$ NMR and ${ }^{1} \mathrm{H}$ NMR spectroscopic data in $\mathrm{CD}_{3} \mathrm{OD}$ of the sugar moieties of compounds 1-6. ${ }^{\mathrm{a}, \mathrm{b}}$

\begin{tabular}{|c|c|c|c|c|c|c|c|c|c|c|c|c|}
\hline & \multicolumn{2}{|r|}{1} & \multicolumn{2}{|r|}{2} & \multicolumn{2}{|r|}{3} & \multicolumn{2}{|r|}{4} & \multicolumn{2}{|r|}{5} & \multicolumn{2}{|r|}{6} \\
\hline & $\delta_{\mathrm{C}}$ & $\delta_{\mathrm{H}}$ & $\delta_{\mathrm{C}}$ & $\delta_{\mathrm{H}}$ & $\delta_{\mathrm{C}}$ & $\delta_{\mathrm{H}}$ & $\delta_{\mathrm{C}}$ & $\delta_{\mathrm{H}}$ & $\delta_{\mathrm{C}}$ & $\delta_{\mathrm{H}}$ & $\delta_{\mathrm{C}}$ & $\delta_{\mathrm{H}}$ \\
\hline \multicolumn{13}{|l|}{ GlcA- } \\
\hline 1 & 104.5 & $4.48, \mathrm{~d}(7.8)$ & 103.9 & $4.46, \mathrm{~d}(7.8)$ & 103.9 & 4.45, d (7.9) & 104.4 & $4.48, \mathrm{~d}(7.8)$ & 105.6 & $4.40, \mathrm{~d}(7.8)$ & 103.2 & $4.22, \mathrm{~d}(7.8)$ \\
\hline 2 & 73.8 & $3.25, \mathrm{dd}(8.9,7.8)$ & 73.7 & $3.216, \mathrm{t}(8.8)$ & 73.7 & $3.25, \mathrm{t}(8.2)$ & 73.7 & $3.21, \mathrm{t}(8.8)$ & 73.9 & $3.26, t(8.7)$ & 73.7 & $3.143, \mathrm{t}(7.8)$ \\
\hline 3 & 76.3 & $3.38, \mathrm{t}(8.9)$ & 76.6 & $3.39, \mathrm{t}(8.9)$ & 76.7 & 3.38 & 76.3 & $3.39, \mathrm{t}(8.9)$ & 76.3 & $3.37, \mathrm{t}(8.7)$ & 76.83 & 3.33 \\
\hline 4 & 71.8 & $3.52, \mathrm{t}(9.3)$ & 72.2 & $3.50-46, \mathrm{t}(9.1)$ & 72.2 & $3.45, \mathrm{t}(8.9)$ & 71.9 & $3.50, \mathrm{t}(9.1)$ & 71.9 & $3.51, \mathrm{t}(9.0)$ & 72.2 & $3.443, \mathrm{t}(9.5)$ \\
\hline 5 & 75.1 & $3.81, \mathrm{~d}(9.1)$ & 75.2 & $3.78, \mathrm{~d}(9.1)$ & 76.775 .2 & $3.69-3.78$ & 75.2 & $3.78, \mathrm{~d}(9.1)$ & 76.5 & 3.75 & 76.2 & 3.42 \\
\hline 6 & 171.3 & - & 172.1 & - & 171.7 & - & 172.1 & - & 171.1 & - & 172.1 & - \\
\hline \multicolumn{13}{|l|}{ Fuc- } \\
\hline 1 & 92.6 & $5.38, \mathrm{~d}(8.2)$ & 92.4 & $5.40, \mathrm{~d}(8.2)$ & 92.6 & $5.35, \mathrm{~d}(8.2)$ & 92.5 & $5.40, \mathrm{~d}(8.2)$ & 92.4 & $5.40, \mathrm{~d}(8.3)$ & 92.4 & $5.40, \mathrm{~d}(8.3)$ \\
\hline 2 & 73.3 & $4.08, \mathrm{dd}(9.4,8.2)$ & 73.1 & $4.11, \mathrm{dd}(9.6,8.2)$ & 74.7 & $4.03, \mathrm{dd}(9.4,8.2)$ & 73.3 & $4.11, \mathrm{dd}(9.6,8.2)$ & 73.1 & $4.11, \mathrm{dd}(9.7,8.3)$ & 73.0 & $4.110, \mathrm{dd}(9.5,8.3)$ \\
\hline 3 & 84.0 & $3.88, \mathrm{dd}(9.9,3.0)$ & 84.2 & $3.87, \mathrm{dd}(10.0,3.1)$ & 74.3 & $3.78, \mathrm{dd}(9.6,3.5)$ & 84.3 & $3.87, \mathrm{dd}(10.0,3.1)$ & 84.2 & 3.87 dd $(9.7,3.1)$ & 84.2 & $3.87, \mathrm{dd}(9.5,3.0)$ \\
\hline 4 & 71.3 & $3.95, \mathrm{~d}(3.0)$ & 71.4 & $3.95, \mathrm{~d}(3.1)$ & 71.8 & $3.62, \mathrm{~d}(3.5)$ & 71.2 & $3.95, \mathrm{~d}(3.1)$ & 71.4 & $3.95, \mathrm{~d}(3.1)$ & 71.4 & $3.95, \mathrm{~d}(3.0)$ \\
\hline 5 & 71.2 & $3.78, \mathrm{~m}$ & 71.3 & $3.78, \mathrm{~m}$ & 71.5 & $3.74, \mathrm{~m}$ & 71.1 & $3.78, \mathrm{~m}$ & 71.3 & $3.78, \mathrm{~m}$ & 71.3 & 3.79 \\
\hline 6 & 15.2 & $1.27, \mathrm{~d}(6.4)$ & 15.1 & $1.28, \mathrm{~d}(6.4)$ & 15.2 & $1.27, \mathrm{~d}(6.4)$ & 15.2 & $1.28, \mathrm{~d}(6.4)$ & 15.1 & 1.27, d (6.4) & 15.1 & $1.27, \mathrm{~d}(6.4)$ \\
\hline \multicolumn{13}{|l|}{ Glc1 } \\
\hline 1 & 102.3 & $4.88, \mathrm{~d}(8.0)$ & 101.9 & $5.03, \mathrm{~d}(8.0)$ & 102.3 & $4.88 \mathrm{~d}(8.0)$ & 102.1 & $4.93, \mathrm{~d}(8.0)$ & 101.9 & $5.03, \mathrm{~d}(8.1)$ & 101.8 & $5.03, \mathrm{~d}(8.1)$ \\
\hline 2 & 74.5 & $3.13, t(8.5)$ & 72.9 & $3.267, \mathrm{t}(8.0)$ & 72.7 & 3.36 & 74.4 & $3.15, \mathrm{t}(8.0)$ & 73.0 & $3.27, \mathrm{t}(9.5)$ & 73.0 & $3.25, \mathrm{dd}(9.3,8.1)$ \\
\hline 3 & 77.0 & $3.36, t(8.5)$ & 78.3 & 4.92 & 77.9 & 4.94 & 76.8 & $3.38, \mathrm{t}(8.3)$ & 78.3 & 4.93 & 78.3 & $4.90, \mathrm{t}(9.3)$ \\
\hline 4 & 69.770 .5 & 3.323 .30 & 68.7 & $3.47, \mathrm{t}(9.0)$ & 68.7 & $3.45, \mathrm{t}(9.0)$ & 70.9 & $3.22, \mathrm{t}(9.3)$ & 68.7 & $3.48, \mathrm{t}(9.4)$ & 68.7 & $3.44, \mathrm{t}(9.3)$ \\
\hline 5 & 76.5 & 3.30 & 76.2 & $3.38 \mathrm{~m}$ & 76.4 & 3.37 & 73.98 & $3.51, \mathrm{~m}$ & 76.2 & 3.38 & 76.2 & 3.36 \\
\hline \multirow[t]{2}{*}{6} & 61.6 & $3.77, \mathrm{dd}(12.0,5.1)$ & 61.4 & $3.79, \mathrm{dd}(12.4,5.9)$ & 61.4 & $3.77, \mathrm{dd}(12.0,5.6)$ & 64.3 & $4.35, \mathrm{dd}(11.7,2.0)$ & 61.4 & 3.78 & 61.4 & $3.79, \mathrm{dd}(12.1,6.4)$ \\
\hline & & $3.93, \mathrm{dd}(12.0,1.8)$ & & $3.93, \mathrm{dd}(12.4,1.8)$ & & $3.93, \mathrm{dd}(12.0,1.8)$ & & $4.389, \mathrm{dd}(11.7,5.2)$ & & $3.93, \mathrm{dd}(12.5 ., 2.2)$ & & $3.92, \mathrm{dd}(12.1,1.8)$ \\
\hline $\mathrm{Ac}-\mathrm{CH}_{3}$ & & & 19.8 & $2.14, \mathrm{~s}$ & 19.8 & $2.14, \mathrm{~s}$ & 19.8 & $2.17, \mathrm{~s}$ & 19.8 & $2.18, \mathrm{~s}$ & 19.8 & $2.12, \mathrm{~s}$ \\
\hline $\mathrm{COO}$ & & & 171.4 & - & 171.2 & - & 172.3 & - & 171.3 & - & 171.4 & - \\
\hline \multicolumn{13}{|l|}{ Glc2 } \\
\hline 1 & 103.9 & $4.63, \mathrm{~d}(7.5)$ & 104.0 & $4.61, d(7.2)$ & & & 104.0 & $4.61, \mathrm{~d}(7.2)$ & 104.0 & $4.60, \mathrm{~d}(7.2)$ & 104.0 & $4.60, \mathrm{~d}(7.0)$ \\
\hline 2 & 73.9 & 3.32 & 74.0 & $3.31-2$ & & & 73.89 & $3.3+3$ & 74.0 & 3.32 & 74.0 & 3.31 \\
\hline 3 & 76.8 & 3.31 & 76.8 & 3.323 & & & 76.8 & $3.3 z 5$ & 76.8 & 3.33 & $76.3-8$ & 3.32 \\
\hline 4 & 70.569 .7 & $3.30-3.32$ & 69.6 & 3.33 & & & 69.8 & 3.334 & 69.6 & 3.32 & 69.6 & 3.31 \\
\hline 5 & 76.5 & 3.283 .30 & 76.5 & 3.340 & & & 76.5 & 3.341 & 76.5 & 3.29 & 76.5 & 3.28 \\
\hline 6 & 60.9 & $3.70, \mathrm{dd}(12.0,5.0)$ & 60.9 & $3.70, \mathrm{dd}(12.4,5.1)$ & & & 60.9 & $3.70, \mathrm{dd}(12.4,5.1)$ & 60.9 & $3.69 \mathrm{dd}(12.1,5.1)$ & 60.9 & $3.69 \mathrm{dd}(12.0,5.0)$ \\
\hline & & $3.85, \mathrm{dd}(12.0,1.7)$ & & $3.85, \mathrm{dd}(12.4,1.8)$ & & & & $3.85, \mathrm{dd}(12.4,1.8)$ & & $3.85 \mathrm{dd}(12.1,1.9)$ & & $3.85(12.0,1.9)$ \\
\hline
\end{tabular}

${ }^{a}$ Overlapped signals are reported without designated multiplicity.

${ }^{\mathrm{b}}$ in $\mathrm{ppm}, J$ in parentheses in $\mathrm{Hz}$. 


\section{Table 3}

${ }^{13} \mathrm{C}$ NMR and ${ }^{1} \mathrm{H}$ NMR spectroscopic data of the aglycone moieties of compounds $7-\mathbf{1 1}$ in $\mathrm{CD}_{3} \mathrm{OD}^{\mathrm{a}},{ }^{\mathrm{a} b}$

\begin{tabular}{|c|c|c|c|c|c|c|c|c|c|c|}
\hline & \multicolumn{2}{|c|}{$\begin{array}{c}7 \\
\end{array}$} & \multicolumn{2}{|c|}{8} & \multicolumn{2}{|c|}{9} & \multicolumn{2}{|c|}{10} & \multicolumn{2}{|c|}{$\begin{array}{r}11 \\
\end{array}$} \\
\hline & $\delta_{\mathrm{C}}$ & $\begin{array}{l}\delta_{\mathrm{H}} \\
\end{array}$ & $\delta_{\mathrm{C}}$ & $\delta_{\mathrm{H}}$ & $\delta_{\mathrm{C}}$ & $\delta_{\mathrm{H}}$ & $\delta_{\mathrm{C}}$ & $\delta_{\mathrm{H}}$ & $\begin{array}{l}\delta_{\mathrm{C}} \\
\end{array}$ & $\delta_{\mathrm{H}}$ \\
\hline \multirow[t]{2}{*}{1} & 38.2 & 1.01 & 38.1 & $1.01, \mathrm{~m}$ & 38.1 & $1.01, \mathrm{~m}$ & 38.2 & 1.00 & 38.2 & $1.01, \mathrm{~m}$ \\
\hline & & $1.63, \mathrm{~m}$ & & 1.63 & & $1.63, \mathrm{~m}$ & & $1.63, \mathrm{~m}$ & & $1.63, \mathrm{~m}$ \\
\hline \multirow[t]{2}{*}{2} & 24.9 & 1.77 & 24.9 & 1.78 & 25.0 & $1.77, \mathrm{~m}$ & 25.0 & $1.78, \mathrm{~m}$ & 24.9 & 1.78 \\
\hline & & 1.94 & & 1.92 & & $1.90, \mathrm{~m}$ & & $1.90, \mathrm{~m}$ & & $1.92, \mathrm{~m}$ \\
\hline 3 & 81.4 & $3.68 \mathrm{dd}(12.0,4.5)$ & 81.5 & $3.67, \mathrm{dd}(12.3,4.7)$ & 82.0 & 3.66, dd $(12.0,4.1)$ & 81.9 & 3.66, dd $(12.1,4.1)$ & 81.4 & $3.68, \mathrm{dd}(12.1,4.1)$ \\
\hline 4 & 42.5 & - & 42.5 & - & 42.5 & - & 42.5 & - & 42.5 & - \\
\hline 5 & 46.8 & 1.26 & 46.7 & $1.26, \mathrm{~m}$ & 46.8 & 1.27 & 46.8 & 1.27 & 46.7 & $1.25, \mathrm{~m}$ \\
\hline \multirow[t]{2}{*}{6} & 17.4 & 1.40 & 17.5 & 1.39 & 17.5 & $1.41, \mathrm{~m}$ & 17.4 & $1.39, \mathrm{~m}$ & 17.5 & $1.39, \mathrm{~m}$ \\
\hline & & 1.52 & & 1.51 & & $1.52, \mathrm{~m}$ & & $1.52, \mathrm{~m}$ & & $1.52, \mathrm{~m}$ \\
\hline \multirow[t]{2}{*}{7} & 32.4 & 1.33 & 32.4 & 1.33 & 32.4 & 1.33 & 32.4 & 1.32 & 32.0 & 1.33 \\
\hline & & 1.68 & & 1.68 & & 1.69 & & 1.66 & & 1.68 \\
\hline 8 & 39.5 & - & 39.4 & - & 39.5 & - & 39.5 & - & 39.5 & - \\
\hline 9 & 46.9 & $1.70, \mathrm{t}(9.9)$ & 46.9 & $1.72, \mathrm{t}(10.3)$ & 46.8 & 1.71 & 46.8 & 1.70 & 46.2 & $1.70, \mathrm{t}(10.3)$ \\
\hline 10 & 36.3 & - & 36.3 & - & 36.3 & - & 36.3 & - & 36.3 & - \\
\hline \multirow{2}{*}{11} & 23.1 & 1.91 & 23.1 & 1.90 & 23.1 & 1.91 & 23.1 & 1.91 & 23.1 & 1.90 \\
\hline & & 1.92 & & 1.92 & & 1.93 & & 1.93 & & 1.92 \\
\hline 12 & 121.9 & $5.31, \mathrm{t}(3.9)$ & 122.0 & $5.31, \mathrm{t}(3.1)$ & 121.9 & $5.32, \mathrm{t}(3.1)$ & 121.9 & $5.32, \mathrm{t}(3.5)$ & 121.9 & $5.32, \mathrm{t}(3.5)$ \\
\hline 13 & 143.5 & - & 143.7 & - & 143.5 & - & 143.5 & - & 143.5 & - \\
\hline 14 & 41.2 & - & 41.2 & - & 41.2 & - & 41.2 & - & 41.2 & - \\
\hline \multirow[t]{2}{*}{15} & 35.0 & 1.32 & 35.4 & 1.32 & 35.7 & 1.33 & 35.5 & 1.33 & 35.5 & 1.33 \\
\hline & & $1.80, \mathrm{dd}(14.7,3.5)$ & & $1.83, \mathrm{dd}(14.1,3.5)$ & & $1.80, \mathrm{dd}(15.1,3.6)$ & & $1.79, \mathrm{dd}(15.2,3.3)$ & & $1.78, \mathrm{dd}(11.5,3.5)$ \\
\hline 16 & 72.7 & $4.77, \mathrm{t}(3.8)$ & 73.0 & $4.62, \mathrm{br} \mathrm{s}$ & 72.7 & $4.77, \mathrm{t}(3.2)$ & 72.7 & $4.77, \mathrm{t}(3.5)$ & 72.7 & $4.77, \mathrm{t}(3.5)$ \\
\hline 17 & 48.5 & - & 48.5 & - & 48.5 & - & 48.5 & - & 48.5 & - \\
\hline 18 & 40.6 & $2.98, \mathrm{dd}(14.2,4.2)$ & 40.5 & $2.99, \mathrm{dd}(14.0,4.0)$ & 40.5 & $2.99, \mathrm{dd}(14.5,4.1)$ & 40.6 & $2.98 \mathrm{dd}(14.5,4.3)$ & 40.6 & $2.98, \mathrm{dd}(14.2,4.6)$ \\
\hline 19 & 46.3 & $1.08, \mathrm{~m}$ & 46.3 & $1.08, \mathrm{~m}$ & 46.3 & $1.08, \mathrm{~m}$ & 46.3 & $1.08 \mathrm{~m}$ & 46.3 & $\begin{array}{l}1.08, \mathrm{~m} \\
2.28 \mathrm{t}(13.9)\end{array}$ \\
\hline 20 & 29.8 & $\begin{array}{l}2.28,1(13.5) \\
-\end{array}$ & 29.9 & ${ }_{-}^{2.30,1(13.0)}$ & 29.9 & $\begin{array}{l}2.28,1(13.5) \\
-\end{array}$ & 29.9 & ${ }_{-}^{2.20}$ & 29.8 & $\begin{array}{l}2.28,1(13.9) \\
-\end{array}$ \\
\hline 21 & 35.1 & $\begin{array}{l}1.15, \mathrm{~m} \\
1.91\end{array}$ & 35.1 & $\begin{array}{l}1.16, \mathrm{~m} \\
1.95\end{array}$ & 35.0 & $\begin{array}{l}1.17, \mathrm{~m} \\
1.92\end{array}$ & 35.0 & $\begin{array}{l}1.17, \mathrm{~m} \\
1.92\end{array}$ & 35.0 & $\begin{array}{l}1.16, \mathrm{~m} \\
1.93\end{array}$ \\
\hline \multirow[t]{2}{*}{22} & 30.7 & 1.69 & 30.7 & 1.69 & 30.0 & 1.69 & & 1.69 & 29.8 & 1.69 \\
\hline & & $1.99, \mathrm{dt}(14.2,4.4)$ & & 1.94 & & 2.01 & 29.9 & 2.01 & & 2.01 \\
\hline \multirow[t]{2}{*}{23} & 63.5 & $3.28, \mathrm{~d}(11.5)$ & 63.5 & $3.28, \mathrm{~d}(11.5)$ & 63.3 & $3.29, \mathrm{~d}(11.6)$ & 63.3 & $3.29, \mathrm{~d}(11.6)$ & 63.5 & $3.28, \mathrm{~d}(11.4)$ \\
\hline & & $3.64, \mathrm{~d}(11.5)$ & & $3.64, \mathrm{~d}(11.5)$ & & $3.65, \mathrm{~d}(11.6)$ & & $3.64, \mathrm{~d}(11.6)$ & & $3.64, \mathrm{~d}(11.4)$ \\
\hline 24 & 12.0 & $0.72, \mathrm{~s}$ & 12.0 & $0.72, \mathrm{~s}$ & 12.0 & $0.73, \mathrm{~s}$ & 12.0 & $0.72, \mathrm{~s}$ & 12.0 & $0.72, \mathrm{~s}$ \\
\hline 25 & 15.2 & $1.01, \mathrm{~s}$ & 15.2 & $1.01, \mathrm{~s}$ & 15.2 & $1.01, \mathrm{~s}$ & 15.2 & $1.01, \mathrm{~s}$ & 15.2 & $1.01, \mathrm{~s}$ \\
\hline 26 & 16.5 & $0.79, \mathrm{~s}$ & 16.5 & $0.78, \mathrm{~s}$ & 16.6 & $0.79, \mathrm{~s}$ & 16.6 & $0.79, \mathrm{~s}$ & 16.6 & $0.79, \mathrm{~s}$ \\
\hline 27 & 26.0 & $1.38, \mathrm{~s}$ & 25.9 & $1.40, \mathrm{~s}$ & 26.0 & $1.38, \mathrm{~s}$ & 26.0 & $1.38, \mathrm{~s}$ & 25.9 & $1.38, \mathrm{~s}$ \\
\hline 28 & 175.7 & - & 175.6 & - & 175.6 & - & 175.7 & - & 175.7 & - \\
\hline 29 & 31.7 & $0.91, \mathrm{~s}$ & 31.9 & $0.91, \mathrm{~s}$ & 31.9 & $0.91, \mathrm{~s}$ & 31.9 & $0.91, \mathrm{~s}$ & 31.9 & $0.91, \mathrm{~s}$ \\
\hline 30 & 23.7 & $0.97, \mathrm{~s}$ & 23.5 & $0.97, \mathrm{~s}$ & 23.7 & $0.97, \mathrm{~s}$ & 23.7 & $0.97, \mathrm{~s}$ & 23.7 & $0.97, \mathrm{~s}$ \\
\hline
\end{tabular}

Overlapped signals are reported without designated multiplicity.

${ }^{\mathrm{b}}$ in ppm, $J$ in parentheses in $\mathrm{Hz}$., 


\section{Table 4}

${ }^{13} \mathrm{C}$ NMR and ${ }^{1} \mathrm{H}$ NMR spectroscopic data in $\mathrm{CD}_{3} \mathrm{OD}$ of the sugar moieties of compounds 7-11.,b

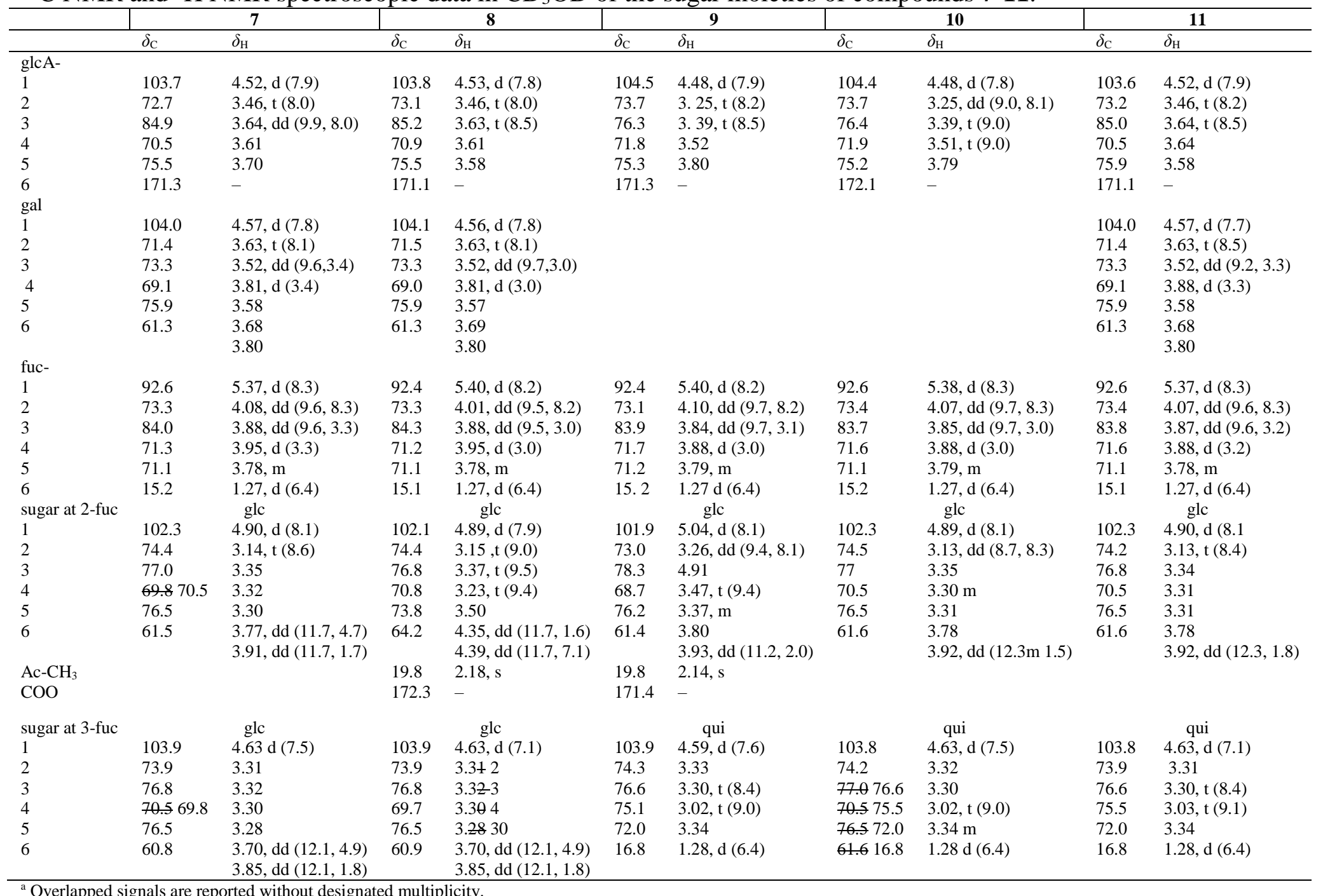

${ }^{\mathrm{a}}$ Overlapped signals are reported without designated multiplicity.
${ }^{\mathrm{b}}$ in ppm, $J$ in parentheses in $\mathrm{Hz}$. 